University of Nebraska - Lincoln

DigitalCommons@University of Nebraska - Lincoln

US Fish \& Wildlife Publications

US Fish \& Wildlife Service

2013

Does location really matter? An inter-colony comparison of seabirds breeding at varying distances from productive oceanographic features in the Bering Sea

Ann Harding

Alaska Pacific University, a.m.a.harding@gmail.com

Rosana Paredes

Oregon State University

Robert Suryan

Oregon State University

Daniel Roby

Oregon State University

David Irons

US Fish and Wilflife Service

See next page for additional authors

Follow this and additional works at: http://digitalcommons.unl.edu/usfwspubs

Harding, Ann; Paredes, Rosana; Suryan, Robert; Roby, Daniel; Irons, David; Orben, Rachael; Renner, Heather; Young, Rebecca; Barger, Christopher; Dorresteijn, Ine; and Kitaysky, Alexander, "Does location really matter? An inter-colony comparison of seabirds breeding at varying distances from productive oceanographic features in the Bering Sea" (2013). US Fish \& Wildlife Publications. 435. http://digitalcommons.unl.edu/usfwspubs/435

This Article is brought to you for free and open access by the US Fish \& Wildlife Service at DigitalCommons@University of Nebraska - Lincoln. It has been accepted for inclusion in US Fish \& Wildlife Publications by an authorized administrator of DigitalCommons@University of Nebraska - Lincoln. 


\section{Authors}

Ann Harding, Rosana Paredes, Robert Suryan, Daniel Roby, David Irons, Rachael Orben, Heather Renner, Rebecca Young, Christopher Barger, Ine Dorresteijn, and Alexander Kitaysky 


\title{
Does location really matter? An inter-colony comparison of seabirds breeding at varying distances from productive oceanographic features in the Bering Sea
}

\author{
Ann Harding ${ }^{\mathrm{a}, *}$, Rosana Paredes ${ }^{\mathrm{b}}$, Robert Suryan ${ }^{\mathrm{c}}$, Daniel Roby ${ }^{\mathrm{b}}$, David Irons ${ }^{\mathrm{d}}$, \\ Rachael Orben ${ }^{\mathrm{e}}$, Heather Renner ${ }^{\mathrm{f}}$, Rebecca Young ${ }^{\mathrm{g}}$, Christopher Barger ${ }^{\mathrm{g}}$, Ine Dorresteijn ${ }^{\mathrm{g}}$, \\ Alexander Kitaysky ${ }^{g}$ \\ a Alaska Pacific University, Environmental Science Department, 4101 University Drive, Anchorage, AK 99508, USA \\ ${ }^{\mathrm{b}}$ US Geological Survey-Oregon Cooperative Fish and Wildife Research Unit, Department of Fisheries and Wildlife, 104 Nash Hall, Oregon State University, \\ Corvallis, OR 97331-3803, USA \\ ${ }^{\mathrm{c}}$ Hatfield Marine Science Center, Oregon State University, 2030 S.E. Marine Science Dr. Newport, OR 97365, USA \\ ${ }^{\mathrm{d}}$ US Fish and Wildlife Service, 1011 East Tudor Road, MS 341, Anchorage, AK 99503, USA \\ e Ocean Sciences Department, University of California Santa Cruz, Long Marine Lab, 100 Shaffer Road, Santa Cruz, CA 95060, USA \\ ${ }^{\mathrm{f}}$ Alaska Maritime National Wildlife Refuge, US Fish and Wildlife Service, 95 Sterling Highway, Homer, AK99603, USA \\ ${ }^{\mathrm{g}}$ Department of Biology and Wildlife, Institute of Arctic Biology, University of Alaska Fairbanks, Irving 311, Fairbanks, AK 99775, USA
}

\section{A R T I C L E I N F O}

Available online 14 March 2013

Keywords:

Corticosterone

Diving

GPS-tracking

Prey

Provisioning

Shelf-break

Stress

\begin{abstract}
A B S T R A C T
Central place foragers, such as breeding seabirds, need to commute between their nests and foraging grounds, thus close proximity of the breeding colony to productive oceanographic features might be beneficial for seabird reproduction. We tested this hypothesis by investigating the at-sea foraging and breeding behavior of thick-billed murres (Uria lomvia) nesting at three colonies (Bogoslof, St. Paul, and St. George Islands) in the Bering Sea located at different distances from the productive continental shelf-break. We found that distances to feeding areas differed only during night trips among colonies. St. Paul murres foraged entirely on the shelf, whereas St. George murres commuted to the continental shelf-break at night and foraged on the shelf during the day. Bogoslof murres foraged in oceanic waters in close proximity to the colony. Murres breeding at the both Pribilof colonies spent less time attending nests and had higher levels of stress hormone corticosterone compared to murres breeding at Bogoslof, although chick-provisioning rates and fledging success were similar among the three colonies. Lower nest attendance and higher corticosterone suggest lower food availability in the Pribilof domain compared to the Bogoslof region. Murres breeding at the Pribilofs used different foraging strategies to buffer effects of food shortages on their reproduction: flight costs associated with longer distance night trips at St. George were presumably balanced by benefits of higher density and/or more lipid rich prey in the continental shelf-break regions, whereas the additional distance of St. Paul from the continental shelf-break may have outweighed any energetic gain. Murres exhibited a remarkable degree of plasticity of foraging strategies in response to changes in their food availability, but the breeding success of murres did not reflect either food limitations or the colony proximity to productive oceanographic features.
\end{abstract}

(c) 2013 Elsevier Ltd. All rights reserved.

\section{Introduction}

Central place foragers commute between their breeding location and foraging grounds to provision offspring (Orians and Pearson, 1979). The amount of food and frequency of meals that can be delivered to offspring is limited both by distance to food

\footnotetext{
* Correspondence to: Alaska Pacific University, Environmental Science Department, 4101 University Drive, Anchorage, AK 99508, USA. Tel.: +1907 4245201.

E-mail address: a.m.a.harding@gmail.com (A. Harding).
}

patches and the amount of time spent foraging within those patches. There is a tradeoff between the time and energetic costs of travel and the energy acquired whilst foraging: Foraging theory predicts that animals should travel the minimum distance to meet energy requirements (Schoener, 1971), and are expected to travel longer distances only if the net energy gain (e.g., due to high-quality, abundant, or easier to capture prey) is higher in distant areas than that in closer areas (Houston and McNamara, 1985; Kacelnik and Cuthill, 1990).

According to Optimal Foraging Theory, foraging behavior should ultimately maximize fitness (Emlen, 1966; McArthur and 
Pianka, 1966). Parents may therefore feed their offspring higher value prey items than they consume themselves because of the nutritional requirements of growth and development (Forero et al., 2002). It may also benefit central place foragers with limited ability to carry and transport prey to deliver fewer, high quality meals to their offspring while feeding on prey of more variable quality because of the costs of transporting food items (e.g., Davoren and Burger, 1999).

The availability of prey to marine predators is highly variable in time and space. Diel vertical migrations of oceanic prey species can result in large temporal patchiness of food availability, with prey brought close to the surface during the night (Moku et al., 2000). Prey are distributed over a large range of spatial scales (Maravelias et al., 1996), with aggregations often described by a nested hierarchical patch structure (Fauchald and Erikstad, 2002; Kotliar and Wiens, 1990; Russell et al., 1992). At larger scales, schools or swarms of prey are often concentrated into patches associated with specific marine habitat requirements, spawning migrations, or meso-scale oceanographic features such as fronts or eddies linked to strong bathymetric relief or circulation patterns (Mackas et al. 2005; Polovina et al., 2001). Seabirds in temperate, sub-arctic and polar regions are strongly attracted to these mesoscale patches, concentrating their foraging near major oceanographic features such as shelf edges and fronts, where prey are abundant and predictable over extended time periods (Hamer et al., 2009; Skov et al., 2008; Weimerskirch, 2007). In contrast, the predictability of prey in oceanic waters is presumably lower, and seabirds show relatively little fidelity to particular feeding locations (Weimerskirch, 2007). Thus, for many seabirds, the proximity of a breeding colony to spatially and temporally predictable high-quality foraging habitats may be important to successfully rear their chicks.

Close proximity to predictable foraging habitat may be especially important for energetically constrained species with high travel costs. Murres (Uria spp.) have elevated flight costs compared to other seabird species because of their small wing area and high wing loading (Pennycuick, 1987), and energy expenditure has been shown to increase with foraging distance (Gaston, 1985a). Murres typically deliver only one prey item at a time to their chick (Houston, 2002), and both frequency of chick meal delivery and chick fledging mass may be limited by the amount of time and energy expended on foraging trips (Davoren and Montevecchi, 2003; Houston et al., 1996). Although both parents share chick-provisioning duties, trip duration and distance is also constrained by the need for one member of the pair to be present with the chick at all times to prevent predation and exposure to poor weather conditions (Birkhead and Nettleship, 1981). Flexible time budgets allow murres to maintain chick-feeding rates (Piatt et al., 2007) and breeding success (Kitaysky et al., 2000) at fairly constant rates over a range of foraging conditions, by allocating more time to foraging when conditions are poor (Harding et al., 2007). However, very little is known about how foraging distances vary under different conditions of food availability (e.g., Wilson et al., 2005). While at-sea surveys are useful for broadscale measures of abundance and foraging distribution (Clarke et al., 2003; Trathan et al., 1998), birds enumerated in these surveys can include a high proportion of non-breeding individuals (Davoren et al., 2003), and it is impossible to determine breeding location when multiple colonies are within commuting distance. A few studies have estimated commuting distances from flight durations obtained by time-depth data loggers (Takahashi et al., 2008; Watanuki et al., 2001), but little is known about actual foraging areas and habitat use of individuals (Benvenuti et al., 1998).

We examined how proximity of the breeding colony to particularly productive oceanographic habitats influences the foraging behavior and breeding performance of thick-billed murres (Uria lomvia) by studying three Bering Sea colonies located at varying distances from productive oceanographic features. A previous study has shown that breeding thick-billed murres can forage up to distances of $168 \mathrm{~km}$ from their colony (Benvenuti et al., 1998). Bogoslof Island is an oceanic colony, surrounded by deep waters ca. $30 \mathrm{~km}$ north of the Aleutian shelfbreak, whereas the two Pribilof Islands are located in the shallow waters of the middle domain of the continental shelf, but at different distances from the continental shelf-break; St. George is located ca. $30 \mathrm{~km}$ from the continental shelf-break, while St. Paul is located ca. $90 \mathrm{~km}$ away (Fig. 1). Both the continental shelfbreak and the Aleutian shelf-break are characterized by elevated productivity, and provide important foraging grounds for seabirds in the Bering Sea (Ladd et al., 2005; Schneider, 1982; Springer et al., 1996). Although murre diets have been quantified at the three colonies (e.g., Iverson et al., 2007; Renner et al., 2012; Sinclair et al., 2008), very little is known about where murres from these colonies forage (Kokubun et al., 2008; Takahashi et al., 2008). Moreover, although there is evidence that Pribilof murres sometimes forage on the shelf, these data are restricted to very few years and the availability of shelf-based prey varies greatly among years (Sinclair et al., 2008).

The Bering Sea has experienced climate shifts in recent decades (Hare and Mantua, 2000), with ocean conditions oscillating between regimes of predominately warm or cold temperatures. Such regimes have been shown to affect the abundance and quality of forage fish and invertebrates (Litzow et al., 2006). Annual variation in oceanographic conditions around the Pribilofs has been shown to influence seabirds breeding on the islands, with higher levels of nutritional stress of piscivorous seabirds during cold years attributed to poor foraging conditions on the continental shelf (Benowitz-Fredericks et al., 2008; Satterthwaite et al., 2012). Key forage fish species, such as the juvenile walleye pollock (Sinclair et al., 2008), are less abundant on the continental shelf during cold years because they either disperse or travel deeper to avoid cold waters (Hollowed et al., 2012). We studied birds in 2009, which was characterized by cold oceanographic

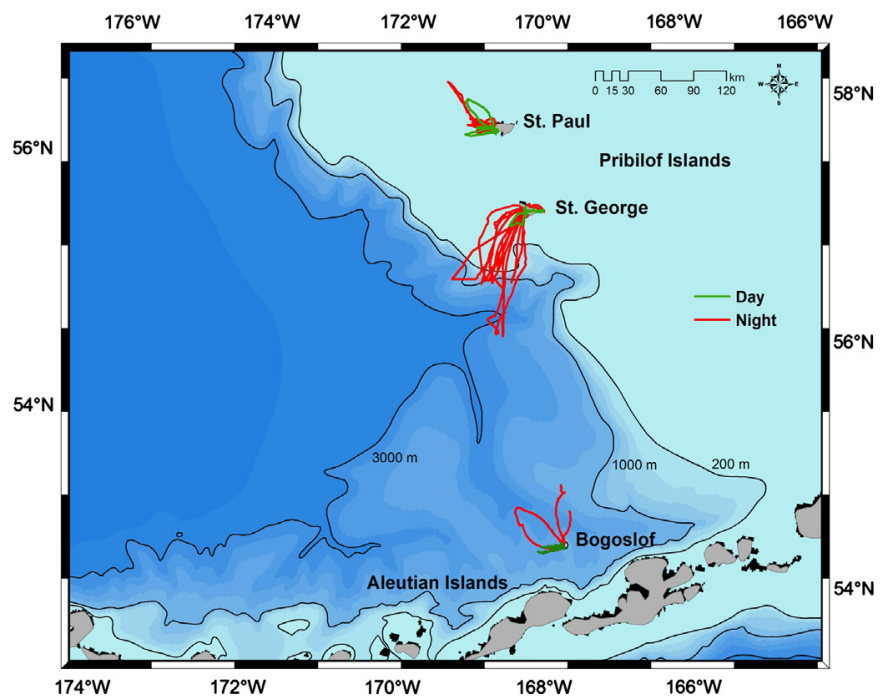

Fig. 1. Study sites in the southeastern Bering Sea. Of the Pribilof Islands, St George is closest to the continental shelf break-slope (200-1000 m isobaths), known as the Bering Sea green belt (see Study System), compared to St Paul. Bogoslof Island is closed to the shelf break-slope of the Aleutian Islands. Day (green) and night (red) foraging trips of thick-billed murres obtained by GPS tracking are shown for each colony (St. George $n=11$ individuals, St. Paul $n=15$, Bogosl of $n=18$ ). 
conditions (Stabeno et al., 2012), providing a good opportunity to examine the importance of accessibility to the shelf-edge for Pribilof birds during years when food availability on the shelf is poor.

Species have different abilities to respond to changes in foraging conditions, and the sensitivity of different parameters therefore differ in their sensitivity to changes in food availability among species (Piatt et al., 2007). The closely related common murre has been shown to buffer chick-feeding rates and fledging success across a wide range in food availability by reallocating discretionary time spent at the colony to foraging effort (Harding et al., 2007; Piatt et al., 2007). Reproductive performance is therefore not a good indicator of foraging conditions (Kitaysky et al., 2000), whereas the behavior of adults (colony nest-attendance; Harding et al., 2007), and blood levels of stress hormones (Kitaysky et al., 2007) have been shown to be directly related to changes in the availability of food resources to chick-rearing murres.

The steroid hormone corticosterone (CORT) plays an important role in an individual's adaptive response to environmental stress (Romero et al., 2000; Wingfield et al., 1998). Individuals have been shown to respond to a number of stressors such as challenging environmental conditions, parasites, and predators by increasing secretion of CORT (e.g., Raouf et al., 2006; Romero et al., 2000). Levels have also been shown to be elevated during food shortages (Kitaysky et al., 1999a, 1999b, 2007, 2010), and in individuals in poor body condition (Kitaysky et al., 1999b; Romero and Wikelski, 2001; but see Schultner et al., 2013). Studies of seabirds have shown that the secretion of CORT is largely driven by changes in food (Benowitz-Fredericks et al., 2008; Kitaysky et al., 1999b, 2007, 2010), and a strong negative correlation between CORT and fish abundance has been demonstrated in a number of seabird populations, including common murres (Uria aalge; Kitaysky et al., 2007). Baseline concentrations of CORT increase in a matter of days in response to food limitation (Kitaysky et al., 2007; 2010), and a number of seabird studies have used CORT as an index of the nutritional status of individuals (e.g., Dorresteijn et al., 2012; Satterthwaite et al., 2010; Schultner et al., 2013; Welcker et al., 2009).

We tested the hypothesis that close proximity of the breeding colony to a productive oceanographic feature is beneficial for breeding murres. We used GPS loggers to determine the foraging location of murres from each colony, and examined how differences in foraging habitat and foraging distance from the colony affect diet, diving behavior, parental time budgets, breeding success, and the nutritional status of parents.

We predicted that breeding murres from Bogosof would commute to the Aleutian shelf-break, and that murres from St. George and St. Paul would commute to the continental shelfbreak. Given the energetic and time constraints associated with a longer commute to foraging grounds, we further predicted that St. Paul murres would experience greater food limitation and spend less time at the colony. Previous tagging studies were done with large seabirds and marine mammals (Le Boeuf et al., 2000; Ryan et al., 2004); this is the first study to use GPS receivers on a smaller diving and flying seabird. We used CORT concentrations in blood plasma as a measure of the energy balance of parents breeding at each colony, and define nutritional stress as when food resources are in lower supply than optimal.

\section{Methods}

\subsection{Study system}

A shelf-break bisects the Bering Sea, separating the shallow continental shelf from the deep waters of the basin hydrographic domain. The edge of the continental shelf has been described as the Bering Sea Green Belt, with the highly productive habitat resulting from physical processes such as crosswise circulation and eddies in the Bering Slope Current, tidal mixing, and advection and upwelling that bring nutrients into the euphotic zone (Coachman and Walsh, 1981; Schumacher and Reed, 1992; Springer et al., 1996). Primary productivity at the shelf break is approximately $60-270 \%$ higher than that in the outer shelf and ocean domains (Springer and McRoy, 1993; Springer et al., 1996). High productivity along the shelf break supports large numbers of zooplankton, fish and squid (Radchenko, 1992; Sinclair and Stabeno, 2002), which in turn attracts high numbers of marine mammals and seabirds (Piatt and Springer, 2003; Schneider, 1982). Further south, the Aleutian Islands form the border between the Bering Sea and the North Pacific Ocean, and the combination of strong currents, abrupt topography and distinct water masses from the two separate water basins promotes high primary productivity and also sustains large numbers of predators (Ladd et al. 2005; Springer et al., 1996).

We studied thick-billed murres breeding at three Bering Sea colonies in 2009. The colonies are located in contrasting oceano-

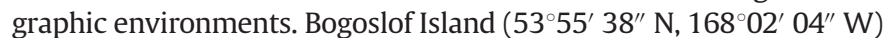
is situated $30 \mathrm{~km}$ north of the Aleutian Chain, adjacent to Aleutian passes and surrounded by deep oceanic waters (1000-2000 m), whereas the two Pribilof Islands are located on the continental shelf and are surrounded by shallower water (100-200 m; Fig. 1). The continental shelf-break is therefore within foraging range of murres from both Pribilof Islands, but is located much nearer to St. George $\left(56^{\circ} 36^{\prime} 20^{\prime \prime} \mathrm{N}, 169^{\circ} 33^{\prime} 35^{\prime \prime} \mathrm{W} ; 30 \mathrm{~km}\right)$ than St. Paul $\left(57^{\circ} 7^{\prime} 30^{\prime \prime} \mathrm{N}\right.$ $\left.170^{\circ} 17^{\prime} 3^{\prime \prime} \mathrm{W} ; 90 \mathrm{~km}\right)$.

\subsection{Field methods}

Field work encompassed the period from pre-lay through to the end of chick-rearing (Bogoslof field work=June 21-Sept 2; median hatch date 21 July (range $=13$ Jul-31 Jul, $n=48$ nests); St. George field work=May 16-Sept 8; median hatch date $27 \mathrm{Jul}$ (range=12 Jul-12 Aug, $n=169$ nests); St. Paul field work=25 May-1 Sept; median hatch date 2 Aug (range=20 Jul-24 Aug, $n=142$ nests)).

\subsubsection{Instruments}

We opportunistically selected thick-billed murres that were rearing chicks 5-15 days old throughout the chick-rearing period, catching them at the nest-site using a telescoping noose-pole (Hogan, 1985). Captures of birds on the Pribilofs were distributed throughout the daylight hours, whereas Bogoslof murres were primarily captured at dawn to maximize the chance of recording active foraging behavior during the battery life of the GPS (see below). Instruments were only deployed on one member of a breeding pair at a time. At initial capture, each bird was weighed $( \pm 1 \mathrm{~g})$ and one or two instruments were attached; a Time-Depth Recorder (TDR), and a GPS (Table 1). Both instruments were

\section{Table 1}

Summary statistics of GPS deployment and logger fate at three Bering Sea colonies, $n=$ individual.

\begin{tabular}{lccc}
\hline & St. Paul & St. George & Bogoslof \\
\hline GPS deployed & 27 & 28 & 32 \\
Birds recaught & 20 & 20 & 30 \\
GPS units recovered & 20 & 17 & 25 \\
GPS units with sufficient data for analysis & 15 & 11 & 18 \\
GPS lost prior to recapture & 3 & 10 & 5 \\
Bird fledged prior to recapture & 1 & 0 & 1 \\
Bird abandoned/nest failed & 1 & 7 & 1 \\
\hline
\end{tabular}


attached to birds on St. George and Bogoslof, but only GPSs were deployed at St. Paul. The TDR was attached to a plastic leg band (Protouch) using zip-ties, and the GPS logger attached to the central back feathers using black Tesa tape ${ }^{\odot}$ (Paredes et al., 2005). GPS loggers were waterproofed prior to attachment using shrink heat tubing (4FT IC8725 3/4 inches clear; Frigid North, AK, USA), heated to mould tightly around the logger and minimize buoyancy. Handling time took ca. 10-15 min, and less than 20 min in all cases. Recapture efforts started approximately $24 \mathrm{~h}$ postdeployment, and birds were recaptured on average after $39 \mathrm{~h}$ (Bogoslof mean $=30$ h; St. George mean=59 h; St. Paul mean= 31 h; Table 1). Upon recapture, all instruments were removed, and body mass was measured again. All individuals were banded with a unique USFWS metal band prior to release.

Lotek TDRs LAT 2500 (mass $=3.6 \mathrm{~g}$, dimensions $=8 \times 35 \mathrm{~mm}$ ) recorded depth and time every $1 \mathrm{~s}$, with an absolute pressure accuracy of $+\mid-1 \%$ of full scale. Two types of TechoSmart GPS loggers with rechargeable batteries were used. The Gipsy-3 (flat antennae: dimensions $41 \times 14 \times 7 \mathrm{~mm}$; total mass $=10 \mathrm{~g}$ ), with a $250 \mathrm{~mA}$ battery was used on Bogoslof, whereas the TechnoSmart Gipsy-2 (flat antenna: dimensions $23 \times 15 \times 6 \mathrm{~mm}$; total mass $=10-14 \mathrm{~g}$ ), with a 250-500 mA battery, was used on the two Pribilof Islands. Latitude and longitude were recorded at intervals of $1-2 \mathrm{~s}$ for $>95 \%$ of positions acquired. Longer time gaps where satellite reception was lost, however, did occur and varied by island, thereby affecting deployment duration (acquiring satellite signal reception requires more battery power than simply recording positions) and the resolution of tracks. GPS units used at St. Paul provided the highest resolution tracks with a mean of 32 positions per minute (range 0.2-58) and mean recording duration of $16 \mathrm{~h}$ [41 maximum] before recovery, followed by St. George (12 positions per minute [0.3-60], $21 \mathrm{~h} \mathrm{[75])}$ and Bogoslof (9 positions per minute [1-34], $11 \mathrm{~h} \mathrm{[25]).} \mathrm{Therefore,}$ a greater number of complete long duration foraging trips (e.g., overnight trips) were recorded at the Pribilof Islands than on Bogoslof.

\subsubsection{Chick diet}

Murres bring a single prey item to their chick, usually held in line with the bill and with a proportion of the prey visible for identification. Identification methods were of three types: all-day watches dedicated to observations of chick diet (St. Paul), ancillary observations made during all-day adult time-budget watches (all three islands), and targeted periods of time dedicated to the digital photography of prey loads using a digital SLR camera [Canon $500 \mathrm{~mm}$ F4, usually with a 1.4 extender (Bogoslof)]. Photographic sessions on Bogoslof were conducted between 0800-2100 Alaska-time, and we therefore restrict the comparison of chick diet among colonies to prey delivered during this time period. A telescope with a 20-60 zoom lens or $10 \times 42$ binoculars were used to identify prey items during the observations sessions; photographed prey were viewed and identified on a computer screen. All prey were identified to the lowest possible taxonomic level and visually assigned to a size category. The three size categories were (S) smaller, (L) larger, or (M) equal to the gape length of the parent.

\subsubsection{Adult diet}

Diet samples of breeding adult murres were obtained using the water off-loading (lavage) method described in detail by Wilson (1984) and for murres by Ito et al. (2010), with the process repeated twice to ensure as complete emptying of the stomach as possible (Neves et al., 2006). Both GPS birds and non-GPS birds were lavaged, and GPS birds were only sampled during their second capture. Total numbers of birds diet-sampled at each island were: St. Paul $n=50$, St. George $n=55$, Bogoslof $n=34$, and captures were distributed evenly during day-light hours. Diet results are presented as percent occurrence (defined as the percentage of samples containing at least one item of a given prey type).

\subsubsection{Parental time Budgets}

We measured parental attendance and chick-feeding rates (feeds $\mathrm{h}^{-1}$ ) at each of the three colonies. Individually marked chick-rearing parents were observed on plots containing 7-13 breeding pairs of murres from sunrise to sunset, during 3-4 observation-days at each of the three colonies. Observation-days were scheduled to sample the early (1-3 August), middle (6-9 August) and late (12-15 August) parts of the chick-rearing phase to control for any change in provisioning behavior with chick age (Birkhead and Nettleship, 1987). Where possible we observed the same nest-sites across chick-rearing, although constraints placed by the need of simultaneous observation of GPS-tagged and untagged birds resulted in fewer observation days at some nests because tagged individuals differed among observation days and observed nests had to be in one field of view.

Parent's arrival and departure time at the colony were noted, along with the time of food delivery to chicks. Attendance was measured in bird-minutes per hour (Harding et al., 2007). For example, where one brooding parent attended its nest for a full hour, and the off-duty partner attended for half of that hour, we calculated 90 bird-minutes of attendance for that hour. Fewer than 60 bird-minutes of attendance would mean that the egg or chick was left unattended for some period of time.

\subsubsection{Corticosterone}

We sampled circulating levels of baseline CORT from breeding adults during the chick-rearing period at each colony to infer the energy balance of parents (St. Paul $n=85$; St. George $n=72$; Bogoslof $n=44)$. These included samples from the initial capture of individuals deployed with GPS units at St. Paul $(n=16)$ and St. George $(n=13)$, All birds were sampled according to a standardized technique (Benowitz-Fredericks et al., 2008), with a blood sample $(<500 \mu \mathrm{l})$ collected within three minutes of capture. After blood collection, all samples were centrifuged, and plasma was preserved frozen for later analysis at the University of Alaska Fairbanks.

\subsubsection{Fledging success}

Fledging success (number of chicks fledged per nests with chicks) was determined at each colony from data recorded during regular observations of sites with eggs (Byrd et al., 2008a; Harris and Wanless, 1988). A minimum of six plots were selected at scattered locations at each colony, and each plot was comprised of 20-30 nests. Nests were checked every 3-6 days, and chicks were considered to have fledged if they disappeared from the nest-site more than $15 \mathrm{~d}$ after hatching (Byrd et al., 2008a; Gaston and Jones, 1998).

\subsubsection{Instrument effect}

We examined: (a) to what extent the instruments may have distorted the normal behavior of the bird, and (b), whether the effect of the device varied among colonies. First, incidences of abandonment and chick-loss post GPS deployment were examined. Second, we examined the effect of instrumentation on behavior by directly observing GPS-tagged birds, and comparing attendance and chick-feeding rates of those birds with controls on the Pribilof colonies (we were unable to observe GPS-tagged birds on Bogoslof due to nesting locations, which were not visible from land). Third, we determined how instrumentation affected the 
physiology of individuals, by (a) comparing changes in mass between tag deployment and recapture at each colony, and (b) comparing changes in baseline CORT levels between deployment and recapture on St. Paul and St. George only. Levels of circulating CORT have been used previously to index the extra energy cost associated with instrumentation (e.g., Takahashi et al., 2008), consequently we collected blood samples from individuals at both initial capture for tagging and recapture.

\subsection{Laboratory analysis}

CORT concentrations (ng $\mathrm{mL}^{-1}$ of plasma) were measured using radioimmunoassays. Each sample was equilibrated with $2000 \mathrm{cpm}$ of tritiated CORT prior to extraction with $4.5 \mathrm{~mL}$ distilled dichloromethane. After extraction, percent tritiated hormone recovered from each individual sample (average hormone recovery was $>87 \%$ ) was used to correct final CORT concentrations. Samples (in duplicates) were reconstituted in PBSG buffer and combined with antibody and radiolabel in a radioimmunoassay. Dextran-coated charcoal was used to separate antibodybound hormone from unbound hormone. All samples were analyzed in five different assays; sensitivity of the assays was $7.8 \mathrm{pg}$ per tube, and inter-assay variation was less than $6 \%$.

\subsection{Statistical analysis}

Location data from GPS units were used to determine foraging range and maximum distance from the colonies. We first used a forward-backward speed filter (McConnell et al., 1992) with a maximum speed of $80 \mathrm{~km} / \mathrm{h}$ (Croll et al., 1991) to cull erroneous positions ( $<5 \%$ of locations were removed), leaving over 1 million locations from 44 individuals. Not all birds were equipped with dive loggers to identify known foraging activity, therefore we developed criteria to define a foraging trip based on activities of birds carrying dive loggers and direct observations of adults returning with prey to provision chicks. According to these criteria, a bird needed to depart a $50 \mathrm{~m}$ buffer around the nest site (selected based on accuracy of GPS position fixes and proximity of nesting location to the ocean) for a minimum of 10 min (the mean minimum duration among islands of a foraging trip resulting in the feeding of a chick during provisioning rate observations) to be included in analyses of foraging activity. We measured the straight-line distance between the nest site and the most distant location of the each central-place trip. In situations where a complete round-trip was not recorded because of GPS failure, we still included the maximum distance estimate in our analysis if the individual began returning to the colony (to within $75 \%$ of the maximum distance). The one exception to this rule was that all night trips of birds from Bogoslof $(n=5)$ were included, even if the GPS failed before the bird began returning to the colony. Most GPS units at Bogoslof stopped recording (due to lower battery capacity from a shore-based, photovoltaic powered charging system) before an entire night foraging trip could be obtained. Therefore, values for Bogoslof represent a minimum estimate of distance traveled from the colony. An overnight trip was defined as beginning on one calendar day and returning the next. Differences in trip distance were examined with a General Linear Model (GLM), with colony, time (day or night), and the interaction between colony and time as factors; and Tukey tests were used for post-hoc comparisons.

We used data from dive loggers to compare maximum depth [per dive] between islands (St. George and Bogoslof) and day vs. night foraging. Although the loggers were set to begin recording at $5 \mathrm{~m}$, the delay in instrument reaction time resulted in the first depth of a dive sometimes recorded as $7 \mathrm{~m}$ if the bird dived rapidly past the $5 \mathrm{~m}$ threshold for initiating depth recording.
A dive was therefore classified as descending greater than $7 \mathrm{~m}$ for $>3 \mathrm{~s}$ (based on an approximate descent rate of $1.1 \mathrm{~m} / \mathrm{s}$ ) and $<4.45$ min (the maximum dive duration based on visual review of dive profiles). Night dives were defined as occurring between evening and morning nautical twilight when the center of the sun is $<12$ degrees below the horizon and no visible sunlight remains. Day dives occurred between sunrise and sunset and crepuscular dives were between nautical twilight and sunrise or sunset. The sun zenith for each location was calculated with the sun position program written in Matlab (Vincent Roy, The MathWorks.com $u$ usersforum) using the latitude and longitude of each island and compared to the United Stated Naval Observatory solar table to verify accuracy.

The proportion of squid vs. fish in chick diet and the relative importance of squid, fish and euphausiid (\% occurrence) in adult diet were compared among colonies using a Chi-square test. We compared time spent at the colony (attendance) and chickfeeding rates obtained from observations among colonies using a GLM, with colony as a factor. Circulating levels of baseline CORT were compared among colonies with an ANOVA, with colony as a factor, and Tukey multiple comparisons were used as post-hoc tests. Similarly, fledging success was compared among colonies with an ANOVA, where average value per plot ( $n=6$ plots at Bogoslof; 12 at St Paul, and 10 on St. George) was used as a sampling unit, and colony as a factor.

To examine the effect of GPS loggers on the behavior of birds observed at the colony, we compared attendance and chickfeeding rates between simultaneously observed GPS and control nests using a GLM, with colony (St. George or St. Paul) and GPS (1 or 0 ) as treatment effects. During prior tests we found no significant effect of nest on either of these parameters, and therefore used nest-day as the sample unit for all subsequent analyses. To determine whether partners were compensating for the reduced performance of the GPS birds (Paredes et al., 2005), we compared the chick-feeding rates of GPS birds and their partner using a paired $t$-test. The mass of birds at deployment of GPS (hereafter 'initial capture') differed significantly among colonies $\left(F_{2,88}=21.64, P<0.001\right)$, with $S$. Paul birds heavier than either St. George or Bogoslof (St. Paul mean $=1104.9 \pm 15.3 \mathrm{~g}$, $n=27$; St. George mean $=987.6 \pm 10.9 \mathrm{~g}, n=28$; Bogoslof mean $=$ $1018.9 \pm 11.6 \mathrm{~g}, n=34)$. To compare changes in body mass during deployment among islands we therefore used mass change as a percentage of mass at initial capture (only birds where GPS loggers remained successfully attached for full deployment were included in this analysis) a GLM was used, with colony as a factor, and the total number of hours deployed included as a covariate. A two-way ANOVA was used to compare mean dive depth between time of day (day, night, and crepuscular) and colony (Bogoslof and St. George). Dive data were log-transformed prior to analysis, and Bonferroni post-hoc multiple comparison tests used. A separate paired $t$-test was used to compare levels of circulating CORT between initial capture and recapture at St. Paul and St. George. CORT data were log-transformed prior to analysis to attain normal distribution.

GPS tracking and dive data were processed using custom programs written in Matlab. Statistical tests were performed in Minitab and SPSS. Statistical significance was assumed at $\mathrm{P}<0.05$. Unless otherwise indicated, values reported are means \pm 1 S.E.

\section{Results}

\subsection{Foraging location}

St. George birds foraged on the shelf during the day and on the continental shelf-break and the basin at night. There was less 
noticeable diurnal difference in the foraging location of murres breeding at St. Paul and Bogoslof: the majority of St. Paul birds foraged on the shelf to the NW of the island, and Bogoslof birds all foraged in the deep water over the basin (Fig. 1). Mean trip

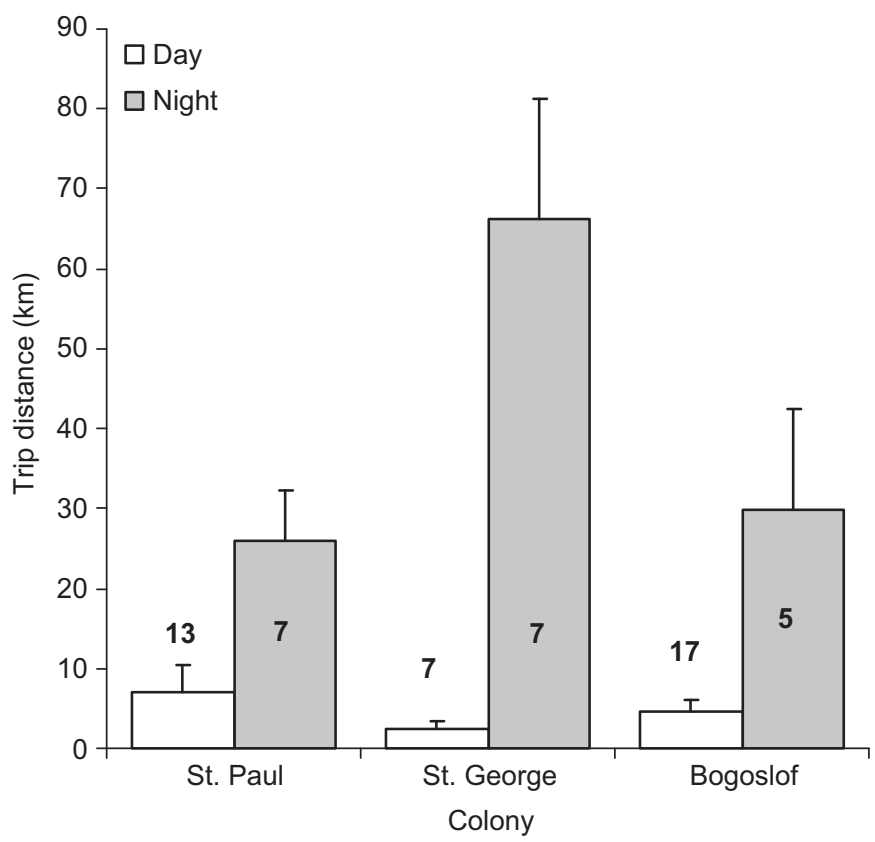

Fig. 2. Trip distances (mean $\pm 1 \mathrm{SE}$ ) of thick-billed murres conducted during the day and night hours at three Bering Sea colonies in 2009 ( $n=$ individual birds).

Table 2

Dive depths $(m)$ conducted during the day, night, and crepuscular hours at Bogoslof and St. George Islands in 2009. Minimum depth used to classify a dive was set at $7 \mathrm{~m}$. Values presented are means among individuals, $n=$ individual.

\begin{tabular}{|c|c|c|c|c|c|c|}
\hline & \multicolumn{3}{|c|}{ St. George } & \multicolumn{3}{|c|}{ Bogoslof } \\
\hline & Night & Day & Crepuscular & Night & Day & Crepuscular \\
\hline$n$ & 11 & 15 & 15 & 12 & 25 & 18 \\
\hline mean & 9.68 & 48.71 & 16.67 & 10.22 & 57.27 & 16.58 \\
\hline SE & 0.43 & 4.31 & 1.69 & 0.50 & 4.86 & 1.18 \\
\hline $\min$ & 8.25 & 27.74 & 8.71 & 7.50 & 21.61 & 8.15 \\
\hline Max & 12.84 & 83.52 & 30.03 & 13.30 & 105.74 & 28.94 \\
\hline
\end{tabular}

distance $(\mathrm{km})$ differed significantly among the three colonies $\left(F_{2,50}=4.50, P=0.016\right)$, with time (day or night; $F_{1,50}=45.19$, $P<0.001$ ), and the interaction between colony and time $\left(F_{2,50}=6.54, P=0.003\right)$. Overall, distances were longer on St. George than either St. Paul or Bogoslof, but there was no difference between St. Paul and Bogoslof (Tukey post-hoc tests $P<0.05$ : St. George mean $=34.4 \pm 11.4 \mathrm{~km}, n=14$; St Paul mean $=13.68 \pm 3.69 \mathrm{~km}, n=20$; Bogoslof mean $=10.26 \pm 3.73 \mathrm{~km}$, $n=22$ ), and trips conducted during the night were longer than those conducted during the day (Tukey post-hoc tests $P<0.05$ : night mean $=41.87 \pm 7.84 \mathrm{~km}, n=19$; day mean $=5.00 \pm 1.42 \mathrm{~km}$, $n=37)$. St. George night trips were significantly longer than both the day trips on St. George and the day and night trips on St. Paul and Bogoslof (Tukey post-hoc tests $P<0.05$; Fig. 2 ), but there was no significant difference in day trip length among colonies.

\subsection{Dive depth}

A total of 10,002 dives from 42 birds were recorded; 5533 dives from 26 birds at Bogoslof, and 4469 from 16 birds at St. George. There was no significant difference in mean dive depth between islands $\left(F_{1}=0.84, P=0.361\right)$, but dive depth differed significantly between the three time periods (day, night, and crepuscular; $F_{2}=194.01, P<0.001$ ), with deeper dives conducted during the day, shallower dives at night, and dives of intermediate depth during the crepuscular hours (Table 2; Fig. 3). The majority of dives performed during the night were less than $20 \mathrm{~m}$ deep at both islands, whereas mean maximum depth per individual conducted during the day ranged from 22-106 m (Table 2; Fig. 3). The maximum dive depth recorded was $142 \mathrm{~m}$ from a bird at Bogoslof.

\subsection{Chick diet}

A total of 712 prey items were observed at the three colonies, and, out of these, 465 (65\%) were visible for some kind of identification. The remaining $35 \%$ were either not identified because the prey were obscured from view or the delivery was too fast. The proportion of fish vs. squid in chick diet differed among the colonies $\left(\chi_{2}=152.61, \mathrm{df}=2, P<0.001\right.$; Table 3$)$ : Bogoslof chicks were fed primarily squid, whereas St. Paul chicks received mostly fish. St. George chicks ate about 75\% fish and 25\% squid. A more detailed breakdown of percentage prey composition is shown in Table 3. The relative proportion of identified fish (at least to family level) was similar on St. George and St. Paul
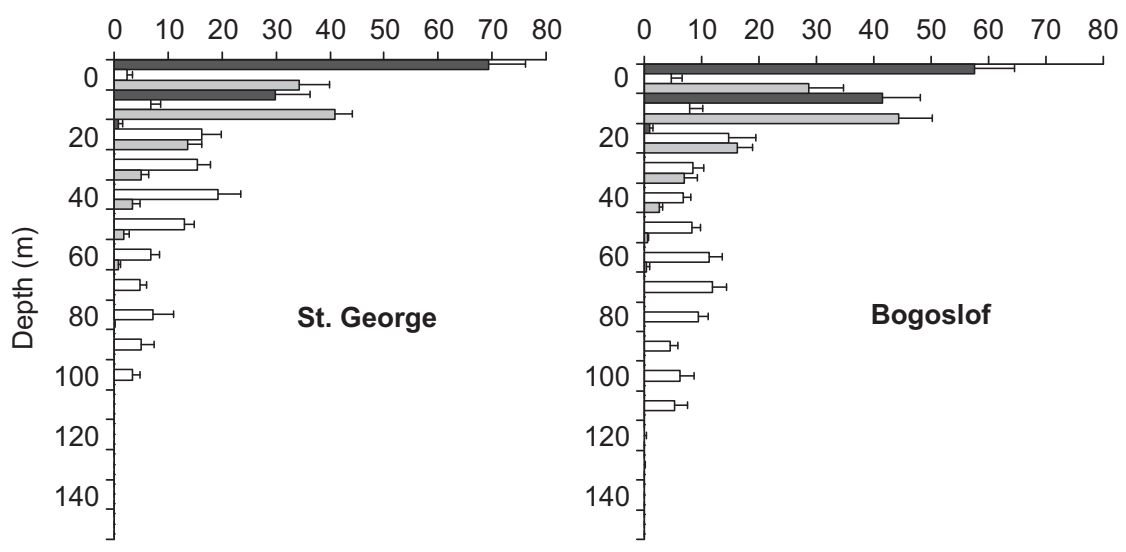

Frequency of occurence (\%)

Frequency of occurence (\%)

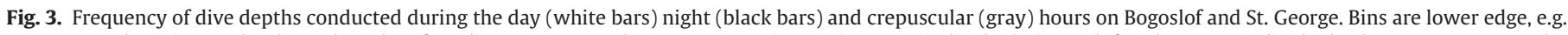

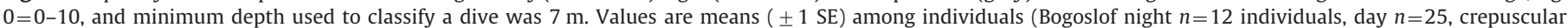
$n=18$; St. George night $n=11$, day $n=15$, crepuscular $n=15$ ). 
Table 3

Percent prey composition of chick diet ( $n=$ prey items) and percent occurrence (defined as the percentage of samples containing at least one prey type) of prey composition of adult ( $n=$ lavage samples) diet of thick-billed murres breeding on three Bering Sea islands in 2009. Dominant prey taxa are shown in bold.

\begin{tabular}{|c|c|c|c|c|c|c|c|}
\hline & \multicolumn{4}{|l|}{ Chick diet } & \multicolumn{3}{|c|}{ Adult diet } \\
\hline & Colony & $\begin{array}{l}\text { St. } \\
\text { Paul }\end{array}$ & St. & Bogoslof & $\begin{array}{l}\text { St. } \\
\text { Paul }\end{array}$ & St. & Bogoslof \\
\hline & $n$ & 110 & 206 & 149 & 48 & 30 & 21 \\
\hline \multirow{13}{*}{$\begin{array}{l}\text { Fish } \\
\text { spp }\end{array}$} & Myctophid & & 0.5 & 6.6 & 2.08 & & \\
\hline & Sandfish & & 0.5 & & & & \\
\hline & Sand lance & 1.9 & 1.0 & & & & \\
\hline & Searcher & & & & 2.08 & & \\
\hline & Smelt & & 1.0 & 0.7 & & & \\
\hline & Unid. Gadid & 4.7 & 0.5 & & 16.67 & 3.33 & 4.8 \\
\hline & Pollock & & & & 72.92 & 23.33 & 9.5 \\
\hline & Flatfish & 1.9 & 4.0 & & & & \\
\hline & Greenling & & 1.0 & & & & \\
\hline & $\begin{array}{l}\text { Eelpout/ } \\
\text { Prickleback }\end{array}$ & 18.9 & 6.9 & & 10.42 & & \\
\hline & Sculpin & & 4.0 & & & & \\
\hline & Gunnel & & & 0.7 & & & \\
\hline & $\begin{array}{l}\text { Unidentified } \\
\text { fish }\end{array}$ & 70.8 & 45.5 & 3.9 & 4.17 & 6.67 & \\
\hline \multirow{7}{*}{$\begin{array}{c}\text { Invert } \\
\text { spp }\end{array}$} & Squid & 1.9 & 34.7 & 85.5 & 4.16 & 76.67 & 90.5 \\
\hline & Euphauslids & & & & & 3.33 & 19.05 \\
\hline & Polychaete & & & & 22.17 & & \\
\hline & $\begin{array}{l}\text { Themisto } \\
\text { Amphipod }\end{array}$ & & & & 2.08 & 3.33 & \\
\hline & Unid. & & & & & 2.08 & \\
\hline & Mollusc & & & & & & \\
\hline & $\begin{array}{l}\text { Unidentified } \\
\text { invert }\end{array}$ & & 0.5 & 2.6 & & & \\
\hline
\end{tabular}

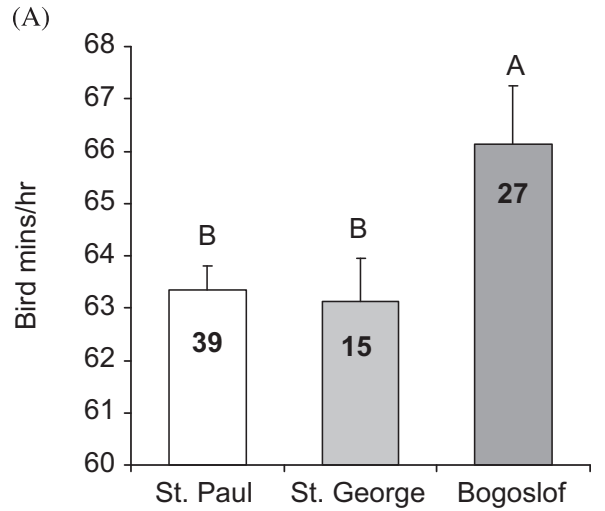

(C)

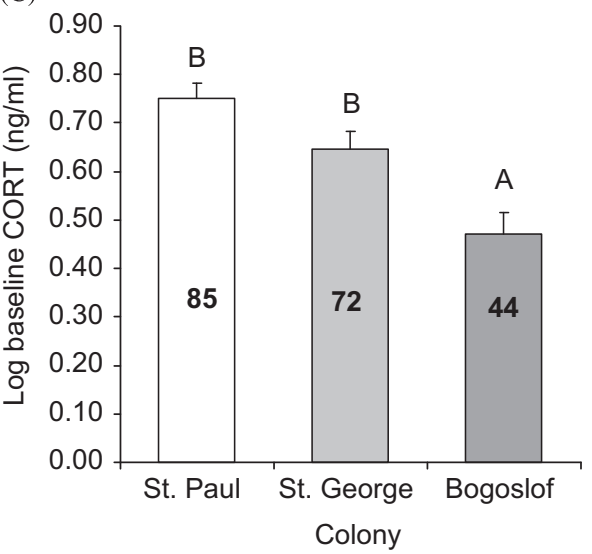

(70-72\% of fish); the majority of identified fish at St. Paul were eelpouts (Zoardidae) and pricklebacks (Stickaeidae), whereas a higher diversity of fish species was identified at St. George.

A total of 563 prey items (Bogoslof $n=166$, St. George $n=280$, St. Paul $n=117$ ) were categorized into three broad prey sizes: smaller than the parent's gape length $(S)$, the same length as the gape $(M)$, and longer than gape length $(L)$. There were no small prey observed on Bogoslof ( $M=23 \%, L=77 \%$ of diet samples), whereas both St. George $(S=26 \%, M=31 \%$, and $L=43 \%)$ and St. Paul $(S=27 \%, M=9 \%$, and $L=64 \%$ ) birds delivered a wider range of prey sizes.

Squid were primarily large at Bogoslof $(B=19 \%, L=81 \%$, $n=130)$; of mixed size at St. George ( $B=31 \%, L=39 \%, S=30 \%$, $n=130$ ), and the single squid observed at St. Paul was large. A similar pattern was observed with unidentified fish relatively large at Bogoslof $(B=20 \%, L=80 \%, n=5)$, and of more mixed sizes at the two Pribilof Islands (St. George: $B=35 \%, L=48 \%, S=17 \%$, $n=91$; St. Paul: $B=7 \%, L=59 \%, S=34 \%, n=71)$.

\subsection{Adult diet}

Adult diet reflected both day and night-time foraging, however, there may be a sampling bias associated with trip duration, with soft-bodied prey collected at night (longer trip duration) likely to be underestimated to a larger extent because of the longer time duration between prey ingestion and lavage. The relative importance of fish, squid and euphausiids (\% occurrence; see methods $)$ in adult diet differed among colonies $\left(\chi_{2}=228.29\right.$, $\mathrm{df}=2, P<0.001$ ); parents on St. Paul fed mostly on fish (primarily juvenile walleye pollock, Theragra chalcogramma, 93\%), whereas

(B)

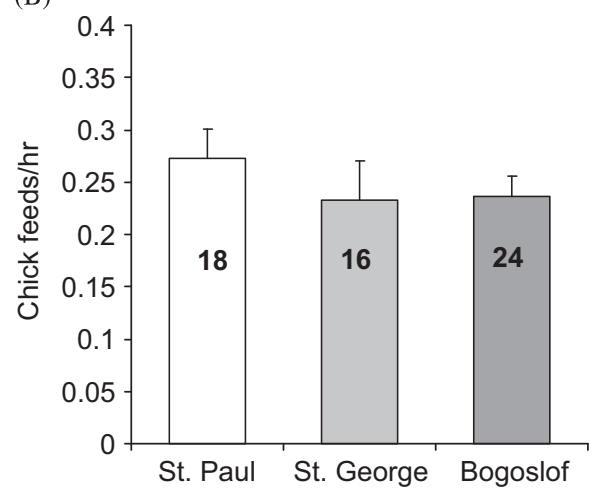

(D)

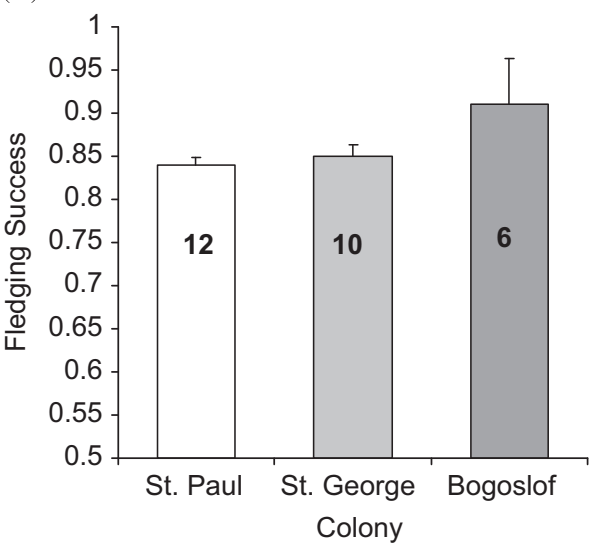

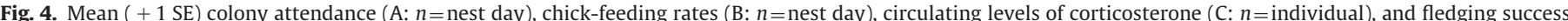
(D: $n=$ plot) of thick-billed murres breeding on St. Paul, St. George, and Bogoslof. Means with different letters are significantly different $(P<0.05)$ 
squid dominated the diet on both St. George (77\%) and Bogoslof (90\%), and euphausiids were most common at Bogoslof (20\%). Pollock was the dominant identified fish species in the diet at both Pribilof Islands (Table 3), and lab dissection of undigested pollock suggests that the ingested polychaete worms were internal fish parasites.

\subsection{Parental time budgets}

Nest attendance differed between colonies $\left(F_{2,80}=4.25\right.$, $P=0.018$ ), with birds spending more time at their nest at Bogoslof than either of the two Pribilof Islands (Bogoslof mean$=66 \pm 1.11 \mathrm{~min} \mathrm{~h}^{-1}, n=27$; St. George mean $=63 \pm 0.81 \mathrm{~min} \mathrm{~h}^{-1}$, $n=15$; St. Paul mean $=63 \pm 0.47 \mathrm{~min} \mathrm{~h}^{-1}, n=39$; Fig. 4). There was no difference in chick-feeding rates among colonies $\left(F_{2,57}=0.64, P=0.529\right.$; Fig. 4$)$; chicks at all three colonies received the equivalent of 3-4 meals in a 16 h day.

\subsection{Corticosterone}

CORT levels differed among colonies $\left(F_{2,198}=12.12, P<0.001\right)$ CORT levels at Bogoslof (log transformed mean $=0.47 \pm 0.046 \mathrm{ng} \mathrm{ml}^{1}$, $n=44$ ) were lower than both St. George (mean $=0.65 \pm 0.036 \mathrm{ng} \mathrm{ml}^{1}$, $n=72$ ) and St. Paul (mean $=0.75 \pm 0.033 \mathrm{ng} \mathrm{ml}^{1}, n=85$ ), but there was no difference in CORT levels between the two Pribilof Islands (Tukey multiple comparison test $P>0.05$; Fig. 4).

\subsection{Fledging success}

Fledging success did not differ significantly among the three colonies $\left(F_{2}, 25=1.39, P=0.267\right)$; and it was high at all three colonies (St. George $=0.85 \pm 0.01, n=10$ plots; St. Paul $=0.84 \pm 0.01$, $n=12$ plots; Bogoslof $=0.91 \pm 0.05, n=6$ plots; Fig. 4 ).

\subsection{Effect of GPS loggers}

Eighty-seven GPS loggers were deployed at the three colonies (Table 1); 70 of these birds were recaptured. Of the 17 loggers not retrieved, nine (10\%) were on birds that abandoned their nests after the instrument deployment and eight (9\%) birds fledged their chicks during the instrument deployment. A total of 44 GPS deployments resulted in usable data [see Methods] for foraging trip analysis (Table 1). These deployments recorded a total of 93 trips (Bogoslof $n=33$, St. George $n=28$, St. Paul $n=32$ ). There was a significant effect of GPS on the attendance of birds at St. Paul and St. George (logger effect: $F_{1,70}=10.44, P=0.002$ ), but no significant difference between the two colonies (logger effect $\times$ colony interaction: $\left.F_{1,70}=0.26, P=0.614\right)$. Birds at control nests spent more time at the colony than birds at nests where one member of the pair was instrumented (control mean= $63.29 \pm 0.41$ bird $\mathrm{min} / \mathrm{h}^{-1}, n=54$ nest-days; GPS nest mean $=$ $60.33 \pm 0.68$ bird $\min \mathrm{h}^{-1}, n=17$ nest-days). Chick-feeding rates did not differ significantly between control and instrumented nests at the Pribilofs $\left(F_{1,51}=2.66, \mathrm{P}=0.109\right.$ : controls $=0.25 \pm 0.28$ feeds $\mathrm{h}^{-1}, n=34$; instrumented $=0.17 \pm 0.05, n=18$ ), or between the two colonies $\left(F_{1,51}=0.00, \mathrm{P}=0.970\right)$. Within nests of instrumented birds, there was no significant difference in chick-feeding rates between the GPS bird and their uninstrumented partner (Paired $t$-test: $T=-1.11_{16}, P=0.282$ ).

Mass change during deployment, calculated as a percentage of mass at initial capture upon recapture, differed significantly among the three colonies $\left(F_{2,63}=4.00, P=0.023\right)$, but did not change with the duration of deployment $\left(F_{1,63}=2.06, P=0.157\right)$. St. George birds lost a higher percentage of their initial body mass than birds from St. Paul and Bogoslof (St. George mean= $-5.25 \pm 1.04 \%, n=18$; St. Paul mean $=-1.47 \pm 0.90 \%, n=20$; Bogoslof mean $=-3.89 \pm 0.85 \%, n=25$ ).

CORT levels of birds at initial capture and subsequent recapture were determined on St. Paul and St. George colonies only (see Methods). There was no significant difference in circulating levels of CORT between the two colonies $\left(F_{1,58}=0.00, P=0.982\right)$, capture period (initial capture and recapture: $F_{1,58}=1.10$, $P=0.298$ ), or the interaction between colony and capture period $\left(F_{1,58}=0.01, P=0.923\right)$.

\section{Discussion}

Our main results can be summarized as: (a) murres nesting at St. Paul did not commute to the continental shelf-break, and instead foraged entirely on the shelf, whereas murres nesting at St. George commuted to the continental shelf-break at night, and foraged on the shelf during the day. Bogoslof murres foraged entirely over the basin relatively close to the colony, and did not commute to the Aleutian shelf-break, (b) levels of food limitation at the two Pribilof Islands were similar, and higher than those at Bogoslof Island, and (c) murres at the Pribilofs spent less time at the colony than Bogoslof birds, but there was no difference in colony attendance between St. George and St. Paul. Below, we discuss these results under four broad categories: (1) Foraging behavior, (2) Diet, (3) Colony attendance, and (4) Instrument effects and performance.

\subsection{Foraging behavior}

Contrary to our predictions, birds on St. Paul foraged entirely on the shelf instead of traveling further distances to the continental shelf-break, St. George birds only traveled to continental shelf-break waters at night, and Bogoslof birds fed entirely in the basin rather than along the Aleutian shelf-break. Although there were technical limitations with the Bogoslof GPS tags, distances estimated from temperature-depth-recorders (much smaller Cefas tags, weight $\sim 2.7 \mathrm{~g}$ ) deployed in the same study year by a simultaneous study were also short (ca. $17 \mathrm{~km}$; C. Barger Unpubl. data). CORT levels suggest that foraging conditions were relatively good at Bogoslof, whereas birds at the two Pribilof Islands were experiencing similar high levels of food limitation. To put our 2009 CORT results into context, the lowest CORT levels (indicative of favorable foraging conditions) in chick-rearing thick-billed murres recorded on St. Paul were in $2005(0.27 \pm 0.09 \mathrm{ng} / \mathrm{ml}$; Kitaysky et al. Unpubl. data), on St. George in 2003 $(0.33 \pm 0.03 \mathrm{ng} / \mathrm{ml}$; Benowitz-Fredericks et al., 2008), and on Bogoslof in 2008 (0.37 $\pm 0.05 \mathrm{ng} / \mathrm{ml}$; Barger and Kitaysky, 2012). CORT levels in 2009 on St. Paul and St. George were therefore $\sim 2$ times higher than the lowest values recorded at these islands. These results have important implications at both the individual and population level, as elevated levels of CORT reduce survival in a number of seabird species, including murres (Kitaysky et al., 2007; Satterthwaite et al., 2010).

Even if it is more profitable to feed in a certain area, murre parents need to balance the costs of longer flight with either more abundant or higher quality prey. Given energetic and time limitations associated with high flight costs and the need for parents to feed their chick 3-5 times per day (Croll et al., 1991), parents may be constrained to feed in less "profitable" areas closer to the colony. Although oceanic domains are thought to be relatively low in productivity (Springer and McRoy, 1993; Springer et al., 1996), deep-water prey are usually high quality, and may be very concentrated near the surface at night due to diel vertical migration even if total productivity of the water column is 
relatively low. Vertically migrating fish, squid, and zooplankton species that live in deep basin waters tend to store large energy reserves so they can fast for extended periods and maintain near neutral buoyancy over a wide range of depths and pressures (Moku et al., 2000; Visser and Jonasdottir, 1999). The diet of seabirds that forage over deep water basins usually include species with relatively high energy densities, such as northern lampfish (Stenobrachius leucopsarus), and northern smoothtongue (Leuroglossus schmidti; Iverson et al., 2007; Lance and Roby, 2000). Lipid values of individual species have also been shown to vary among habitats, and a recent study on the energy density of forage fish and invertebrates in the southeastern Bering Sea has shown that the lipid values in squid varied from $9-52 \%$, with energy values higher in the slope region than over the shelf (Whitman, 2010). Therefore, the prey species available in the deep basin waters around Bogoslof and off the shelf near the Pribilofs were of substantially higher quality than those available on the shelf. Distances traveled by Bogoslof birds at night were equivalent to the distance to the Aleutian edge, suggesting that prey profitability was higher in the deeper basin waters than along the chain. Although we recorded very few night trips on Bogoslof, a simultaneous study on the diet (measured by stable isotopes) and foraging behavior (measured by temperature depth recorders) supports our findings, showing that thick-billed murres on Bogoslof were eating squid and euphausiids, and conducting relatively short-distance trips from the colony (ca. $17 \mathrm{~km}$; C. Barger Unpubl. data). Interestingly, the day-time foraging locations of Bogoslof birds also suggest that energy gained from prey in the basin outweighed any benefits associated with traveling further distances to the Aleutian chain, despite the absence of diurnal vertical migration. Further study is now required to understand the day-time availability of basin-based prey. St. George birds were able to forage in the basin at night, when they were free from day-time chick-provisioning constraints, but it was energetically unfeasible for St. Paul birds to make the long commute to the basin, despite the higher quality prey available in the basin.

Birds on both St. George and St. Paul foraged on the shelf during the day, despite evidence of energy limitation. These results suggest that it was energetically beneficial for birds at both islands to forage closer to the colony when feeding their chick. Perhaps food availability on the shelf in 2009 was sufficient to outweigh the additional energetic and time costs associated of commuting to the continental shelf-break/basin, and/or chick provisioning requirements confined day-time foraging trips. Certainly, previous studies have shown that Pribilof murres sometimes forage on the shelf in frontal areas associated with tidal currents and bottom topography (Decker and Hunt, 1996; Kokubun et al., 2008), with foraging efforts often focused below the thermocline in stratified water (Kokubun et al., 2008; Takahashi et al., 2008).

Interestingly, when experiencing similar levels of food limitation, St. Paul and St. George birds employed different behavioral strategies. St. George birds traveled longer distances to forage at the continental shelf-break and in the basin at night, but these flight costs were presumably balanced by the benefits of feeding on higher density prey aggregations, and/or more lipid rich prey (squid) than birds on St. Paul (Pollock; Van Pelt et al., 1997). The energy value of squid has been shown to vary among species, and even be similar to pollock (Logerwell and Schaufler, 2005). However, a recent study has shown that squid in the Southeastern Bering Sea have higher energy value than the Gulf of Alaska (Van Pelt et al., 1997; Whitman, 2010), with squid caught on these surveys having higher total energy value per individual (19.26 kJ) than northern lampfish (11.37 kJ; Heppel and Benoit-Bird unpubl. Data).

Although St. George and St. Paul are situated close to each other, the two Pribilof Islands have different habitat availability
(Schneider and Hunt, 1984). The closer proximity of St. George to the continental shelf-break may buffer birds from changes in food availability on the shelf, whereas birds on St. Paul may be more vulnerable to climate effects on food resources in the shelf regions (Byrd et al., 2008a, 2008b). There is accumulating evidence for changes in biological communities associated with ecosystem shifts in the Bering Sea (Grebmeier et al., 2006), and it has been suggested that the prolonged regimes observed during the last decades may be detrimental to populations of seabirds and northern fur seals (Callorhinus ursinus) breeding at the Pribilof Islands (Stabeno et al., 2012). Piscivorous birds on the Pribilofs have been shown to experience greater food limitation during cold years (Kitaysky, Unpubl data; Benowitz-Fredericks et al., 2008; this study; Satterthwaite et al., 2012), and a recent analysis of the relationship between environmental variables, productivity and CORT levels of seabirds suggests a potential decline of both Pribilof colonies if current cold conditions persist in the North Pacific (Satterthwaite et al., 2012). Although there were relatively cold conditions for the Bering Sea in 2009 (Stabeno et al., 2012) and murres breeding on both Pribilof Islands were more foodlimited (higher CORT and lower co-attendance compared to Bogoslof), St. Paul birds were able to attain a similar level of energy balance as birds on St. George. However, this might not always be the case, for example if foraging conditions on the shelf deteriorate further, the additional distance to the productive continental shelf-break may be cost-prohibitive for murres to reproduce successfully on St. Paul Island. Conditions on St. Paul have certainly been shown to be poorer than St. George at least in some years, with higher CORT levels (Benowitz-Fredericks et al., 2008) and lower chick-feeding rates (Kitaysky et al., 2000).

Interestingly, there was very little difference in the distance of foraging trips conducted during the day among the three colonies, with birds feeding on average ca $5 \mathrm{~km}$ from a colony. Birds at all three colonies traveled further distances at night, and this pattern was most pronounced on St. George. Many species of seabird alternate short foraging trips (which maximize food delivery to their offspring) with longer self-feeding foraging trips (to replenish their own energy reserves; Chaurand and Weimerskirch, 1994; Weimerskirch et al., 1994). In murres, the distance of trips conducted during the day might be limited by the need to provision the chick a total of 3-4 meals day ${ }^{-1}$ during daylight hours and the necessity for one parent to brood the chick continuously. In this study, we observed a large diurnal/nocturnal difference in foraging range, with birds at all three colonies conducting longer trips at night. Although there is some evidence that murres conduct both long and short trips under certain environmental conditions (Benvenuti et al., 1998; Watanuki et al., 2001), further study is required to examine differences between day and night trip distances and the variability in night behavior under different environmental conditions and among colonies at different latitudes.

Birds at both St. George and Bogoslof conducted shallower dives at night, and the frequency of these shallow dives may even be underestimated because logger-settings prevented the recordings of depths less than $7 \mathrm{~m}$ (see Methods). Thick-billed murres on St. George have previously been shown to dive to depths no deeper than $5 \mathrm{~m}$ during the period of darkness, with dive depths becoming deeper as the sun rose (Takahashi et al., 2008). Shallow night dives most likely reflect a greater abundance of prey in the epipelagic layer due to diel vertical migration (Katugin and Zuev, 2007; Kooyman et al., 1992), lower light conditions for pursuit hunting, or both. A recent Bering Sea study linking observations of murres with the vertical accessibility and availability of their prey clearly shows that murres were conducting shallower dives at night in response to the diel migration of prey (Benoit-Bird et al., 2011). Some of the day-time foraging behavior will reflect dives 
for larger prey located at depth for chick provisioning (Ito et al., 2010); however, the majority of the dives conducted during the day were probably dedicated to self-feeding. Piatt et al. (2007) estimated that relatively little extra food-energy is required for murre parents to feed their chick: i.e., based on measurements of field metabolic rates (FMR; Gabrielsen, 1994) and assimilation efficiency (87\%; Romano et al., 2006), murres need to capture about $512 \mathrm{~g}$ of fish (at $5.0 \mathrm{~kJ} \mathrm{~g}^{-1}$ wet mass), the equivalent of about $49 \%$ of their body mass. Despite this large daily food requirement for self-maintenance, raising a single chick only increases a parent murre food demands by about $8 \%$, which might explain why we did not observe inter-colony differences in chick feeding rates.

\subsection{Diet}

Inter-colony differences in diet reflect the differences in foraging habitat. Our data indicated that Bogoslof birds were both self-feeding and provisioning their chick primarily on squid caught in the basin. Although squid are common mesopelagic prey in the Bering Sea that migrate to the upper $200 \mathrm{~m}$ at night (Sinclair et al., 1999), their predominance in both adult and chick diet on Bogoslof suggests availability at depths $\leq 100 \mathrm{~m}$ during daylight hours. Squids of the family Gonatidae dominate the epipelagic cephalopod assemblages in the western Bering Sea. The majority of squid found in the top $50 \mathrm{~m}$ of the water column are at early stages of their development, and may have a limited ability to conduct diel vertical migration (Katugin and Zuev, 2007). Squid are a significant source of prey for many seabird species (see Croxall and Prince, 1996 for a review), and more study is required on species identification, their availability in the water column, and their nutritional value to seabirds. The occurrence of euphausiids in the adult diet (but not in chick diet) on Bogoslof supports the predictions of Central Place Foraging Theory (Orians and Pearson, 1979), with parents minimizing transport costs by provisioning prey items to their offspring that are larger and energetically richer than prey they ingest themselves (e.g. Gaston and Hipfner, 2000).

Chick diet on St. Paul reflects the birds' relatively near-shore foraging behavior, with an abundance of pricklebacks and eelpouts (both benthic species), whereas St. Paul murre parents fed primarily on the (pelagic) pollock that were available on the shelf to the NW of the island in 2009 (Janelli et al., 2009). Diet at St. George was intermediate between St. Paul and Bogoslof, presumably reflecting the proximity of the island to both shelf and basin habitats. Parents were primarily foraging at night on or near the continental shelf-break, an area of high production where both squid and fish are known to concentrate and at least one important squid species (Berryteuthis magister) spawns (Sinclair and Stabeno, 2002; Sinclair et al., 2008). However, both the dominance of squid in parental diet and their presence in chick diet suggests that a good proportion of squid were caught on the shelf during the day. The relatively high diversity of fish delivered to chicks at St. George could reflect the high diversity of local marine habitat (Sinclair et al., 2008), lower abundance of prey in general (Schoener, 1971), or a greater ability to identify fish by observers at the colony.

A total of 99 (71\%) of the 139 collected lavage samples had prey remains. The number of empty samples differed among colonies; only $4 \%$ were empty on St. Paul, while $40 \%$ were empty on St. George, and 38\% on Bogoslof. Differences in numbers of empty samples either reflect variation in sampling effectiveness among field-workers (which is unlikely because all field crews received training and followed the same lavage protocol), or differential digestion rates for different prey species (Furness et al., 1984; Wilson et al., 1985), the effect of meal size on digestion rates (Neves et al.,2006), and time of ingestion relative to water flushing (Neves et al., 2006). Certain prey species, such as euphausiids, may be underestimated with this method because hard parts of prey are relatively resistant to digestion compared to soft-bodied prey, whereas cephalopods, in particular, may be overestimated due to the persistence of beaks in the stomach (Furness et al., 1984). Although methods in our study were similar among colonies, the shorter duration of GPS deployment and distance of trips at night on St. Paul and Bogoslof may have resulted in a greater probability of recovering soft-bodied prey species than on St. George. This potential sampling bias may partly explain the higher proportion of squid in the diet of St. George adults than St. Paul, however, the difference is likely to be real because chicks on St. George were also fed more squid, and previous studies have shown that both seabirds and northern fur seals (Callorhinus ursinus) on St. George generally consume more squid than St. Paul (Sinclair et al., 2008). Given constraints with differential digestion time of prey, stable isotope analysis may be a more appropriate method to quantify adult diet (Barger and Kitaysky, 2012), although it would be impossible to distinguish between adult diet collected during day and night trips with this method.

\subsection{Colony attendance}

Murres have highly flexible time budgets, and have been shown to buffer chick-feeding rates and breeding success over a range of food availabilities, by allocating more time to foraging when conditions are poor (Harding et al., 2007). Our results support the flexible time budget hypothesis, with parents at both Pribilof Islands experiencing relatively poor foraging conditions, but maintaining similar chick-provisioning rates and fledging success by spending more time foraging than Bogoslof birds. However, this flexibility is not without its potential long-term costs, and high levels of CORT (Brown et al., 2005; Kitaysky et al. 2007, 2010; Romero and Wikelski, 2001), and increased parental effort (Golet et al., 1998) may be detrimental to adult survival. Although colony attendance differed among colonies by only $3 \mathrm{~min} \mathrm{~h}^{-1}$, this translates to an extra $48 \mathrm{~min}$ in a $16 \mathrm{~h}$ day diverted to foraging. Harding et al. (2007) showed that provisioning rates are a non-linear function of colony attendance in the closely related common murre. In this study, chick-feeding rates plateaued at 4.3 meals $16 \mathrm{~h}^{-1}$ day over a wide range in the amount of time parents spent at the colony. Only when attendance dropped below 63 bird min day ${ }^{-1}$-equivalent to the nonbrooding parent spending less than 50 min day $^{-1}$ at the colonydid provisioning rate diminish. These results suggest that attendance levels at the Pribilofs (63 min) may be at or near this lower threshold, and chick-feeding rates may start to decrease if foraging conditions deteriorate further.

Discretionary time spent at the colony and the relatively low CORT levels of parents on Bogoslof suggests that food in the basin may have been higher density and/or higher quality than on the shelf near the Pribilof Islands. However, although parents on Bogoslof had discretionary time available at the colony, they did not increase their provisioning rates. Perhaps there is little benefit for parents to feed offspring more than $3-4$ meals day ${ }^{-1}$. Murre fledgling survival may not be as closely linked to condition at colony departure as in other species because chicks leave the colony at only 15-30\% adult body mass, and are fed at sea by the male parent for an extended period of time (Gaston, 1985b). Certainly, wild murre chicks have been shown to consume under their maximum limit (Harris and Wanless, 1995). Alternatively, murre parents may have limited ability to increase parental effort (Erikstad et al., 1997; Kitaysky et al., 2000; but see Paredes et al., 2005). Or, chick feeding rates may be constrained by the need for 
parents to spend time at the colony, with colony attendance by both parents more important on Bogoslof because of the presence of predatory glaucous-winged gulls Larus glaucescens (Martindale, 1982), whereas there are almost no avian predators on the Pribilof Islands. Although more complete data are needed on fish identification and the nutritional value of squid, the higher proportion of larger prey items on Bogoslof Island suggests chicks were receiving more energy than chicks on the Pribilofs despite the similarity in provisioning rates among colonies. However, given that common murres chicks have been shown to survive on much less energy than that required for optimal growth (BenowitzFredericks and Kitaysky, 2005), it is not surprising that presumed differences in chick daily energy intake among colonies were not translated into measures of fledging success.

\subsection{Instrument effects and performance}

Although GPS locations obtained in this study were frequent enough to estimate and compare maximum foraging distances among islands, deploying GPS loggers on a small diving and flying bird proved challenging. Several loggers were pecked off or damaged during deployment, and GPS loggers stopped recording data when birds were diving. The variation in gap duration presumably reflected both differences in dive duration and the time required for GPS units to reacquire satellite reception.

There is increasing evidence that data loggers can affect the behavior of birds (e.g., Passos et al., 2010; Wilson et al., 2002). GPS units used in this study weighed between 10-14 g, and total instrumentation weight, including TDR (3.6 g), bands and tesa tape ( $4 \mathrm{~g}$ ) was therefore about 20-21 g or approximately $2 \%$ of the average initial mass of GPS birds in this study (mean $=1033.86 \pm$ $8.89 \mathrm{~g}, n=87$ ). Although this mass is below the suggested threshold of 3\% body mass (Philips et al., 2003), and light compared to other loggers previously used on murres (see Takahashi et al., 2008 for summary), the necessity of a back-attachment is not ideal for diving birds and will have increased the effect of drag whilst underwater (Tremblay et al., 2003). Thus, whilst it is unlikely that instrumentation had no effect, it is important to determine (a) to what extent the instruments distorted the normal behavior of the bird, and (b), whether the effect of the device varied among colonies.

Evidence of an effect of instrumentation on individual behavior is mixed. GPS birds were observed provisioning their chick, the vast majority of GPS nests successfully reared a chick, and the comparison of baseline CORT between deployment and recapture suggested negligible short-term physiological effect. However, parents at instrumented nests spent more time away from the colony, and feeding rates suggests some reduction in chick provisioning by the instrumented birds and compensatory behavior by their partners (Paredes et al., 2005). Dives conducted by birds on St. George and Bogoslof were similar to those previously recorded for the species (Hedd et al., 2009; Takahashi et al., 2008). Furthermore, although, birds at all three colonies lost mass during deployment on average, mass loss during the breeding season may be an adaptive adjustment for reducing flight costs and increasing foraging efficiency (Croll et al., 1991), and we have no measure of mass loss on control (non-tagged) birds to determine logger effect.

Evidence on whether the effect of the device varied among colonies is also unclear. The effect of instrumentation on chickfeeding rates and attendance did not differ between St. George and St. Paul, and changes in CORT during deployment were similar between the two colonies. However, overall, $10 \%$ of nests where GPS loggers were deployed failed post-deployment, but this percentage was higher on St. George (25\%) than both St. Paul (4\%) and Bogoslof (3\%), despite the similarity in fledging success among islands. St. George birds also lost the highest percentage of their initial body mass. Longer night foraging distances in combination with the dual instrument deployment (GPS and TDR) and lighter body mass of birds on St. George may explain why nest failure, recapture time, and loss of body mass during deployment were higher at St. George compared to those at St. Paul. While levels of abandonment in this study were not significant at a population level, more thorough tests are required to truly determine the influence of tags on the behavior of this species. Such tests could include the comparison of CORT and mass change between tagged and non-tagged birds over the same time period, and comparing the flight distance and dive behavior estimated from birds deployed with GPS units versus small time-depth recorders attached to the leg.

\subsection{Conclusions}

Foraging strategies of marine predators have been shown to vary both among species and populations (Lewis et al., 2001), and the comparison of foraging behavior under different environmental conditions can help disentangle the various life-history, ecological and physical constraints on foraging behavior. Our study suggests that murres may have more flexibility to adjust foraging distances at night rather than changing their behavior during the day when chicks need frequent provisioning. Further study is now needed to examine variability in day and night-time behavior over a range of environmental conditions, and determine whether monitoring night behavior would provide a better indication of local prey availability than conventionally measured day trips.

Murres exhibited remarkable plasticity in foraging strategy among breeding colonies, even between the two colonies situated within commuting distance of each other. This flexibility appears key for allowing thick-billed murres to nest successfully in a wide range of colony environments. However, this flexibility is not without its potential long-term costs on adult survival, and even a small change in adult survival of long-lived species will have a large effect on population size (Doherty et al., 2004). Our results also suggest that the relative importance of productive oceanographic features for foraging seabirds varies according to the location of the colony and general productivity of the local area. Foraging theory predicts that individuals should travel the minimum distance to meet energy requirements (Schoener, 1971), and Bogoslof birds were able to maintain a high energy balance by foraging entirely in the deep oceanic waters surrounding the colony. Further work is needed to assess whether productivity in basin waters surrounding Bogoslof is influenced by passes in the Aleutian Chain that promote high productivity through powerful tidal mixing and the upwelling of nutrients (Mordy et al., 2005). Although colony proximity to important oceanographic features did not totally explain inter-colony differences in food limitation in 2009, the closer proximity of St. George to the continental shelf-break and access to higher energy basin-based prey may be an important buffer in years when food supply on the shelf is poor (Byrd et al., 2008b).

\section{Acknowledgment}

This publication number is NPRB \#377 BEST-BSIERP Bering Sea Project \#76. We are indebted to B. Battaile, D. Cushing, B. Drummond, T. Harten, D. Kildaw, R. Marshall, R. Massengale, R. Papish, T. Vergoz, J. Warzybok, A. Will, and S. Youngren for their dedication and skill in the field, A. Will and B. Battaile for designing the observation data-base, R. and J. Irons for assistance with pressure testing the GPS casing, E. Kitaiskaia for conducting 
hormonal analysis, and K. Turco for her invaluable expertise and patience with the lavage analysis. Many thanks to G. Dell'Omo (Technosmart) and Mike Vandertillaart (Lotek) for their technical support throughout the season. We thank K. Holser (St. George Island Institute), P. Wohl and A. Purcella (Northern Forum), P. Zavadil and D. Lestenkof (Aleut Community of St. Paul Island), S. Merculief (Tribal Council St. George Island), K. Brenneman, J. Reed, L. Spitler, J. Williams, and the crews of the MV Tiglax and Miss Alyssa for crucial logistical and financial support. We are grateful to stimulating discussions with other members of the BSIERP projects led by A. Trites, S. Hepell, K. Benoit-Bird, and K. Kuletz. All procedures have been approved by the Institutional Animal Care and Use Committee, University of Alaska, Fairbanks, and conducted under IACUC permit \#2009008. This study was funded by NPRB, BSIERP Project B63 and B77 to D.B. Irons, D.D. Roby, and A.S. Kitaysky, and Project B65 to H.M. Renner and G.V. Byrd.

\section{References}

Barger, C.P., Kitaysky, A.S., 2012. Isotopic segregation between sympatric seabird species increases with nutritional stress. Biol. Lett. 8, 442-445.

Benoit-Bird, K.J., Kathy, K., Heppell, S., Jones, N., Hoover, B., 2011. Active acoustic examination of the diving behavior of murres foraging on patchy prey. Mar. Ecol. Prog. Ser. 443, 217-235.

Benowitz-Fredericks, Z.M., Kitaysky, A.S., 2005. Benefits and costs of rapid growth in common murre chicks Uria aalge. J. Avian Biol. 36, 287-294.

Benowitz-Fredericks, Z.M., Shultz, M.T., Kitaysky, A.S., 2008. Stress hormones suggest opposite trends of food availability for planktivorous and piscivorous seabirds in two years. Deep-Sea Res. II 55, 1868-1876.

Benvenuti, S., Bonadonna, F., Dall'Antonia, L., Gudnundsson, G., 1998. Foraging flights of breeding thick-billed murres (Uria lomvia) as revealed by bird-born direction recorders. Auk 115, 57-66.

Birkhead, T.R., Nettleship, D.N., 1981. Reproductive biology of thick-billed murres (Uria lomvia): an inter-colony comparison. Auk 98 (2), 258-269.

Birkhead, T.R., Nettleship, D.N., 1987. Ecological relationships between common murres, Uriaaalge, and thick-billed murres, Urialomvia, at the Gannet Islands, Labrador. III. Feeding ecology of the young. Can. J. Zool. 65, 1630-1637.

Brown, C.R., Brown, M.B., Raouf, S.A., Smith, L.C., Wingfield, J.C., 2005. Effects of endogenous steroid hormone levels on annual survival in cliff swallows. Ecology 86, 1034-1046.

Byrd, G.V., Schmutz, J.A., Renner, H.M., 2008a. Contrasting population trends of piscivorous seabirds in the Pribilof Islands: A 30-year perspective. Deep-Sea Res. II 55, 1846-1855.

Byrd, G.V., Sydeman, W.J., Renner, H.M., Minobe, S., 2008b. Responses of piscivorous seabirds at the Pribilof Islands to ocean climate. Deep Sea Res. II 55, 1856-1867.

Chaurand, T., Weimerskirch, H., 1994. The regular alternation of short and long foraging trips in the blue petrel Halobaena caerulea: a previously undescribed strategy of food provisioning in a pelagic seabird. J. Anim. Ecol. 63, 275-282.

Clarke, E.D., Spear, L.B., McCracken, M.L., Marques, F.F.C., Corchers, D.L., Buckland S.T., Ainley, D.G., 2003. Validating the use of generalized additive models and at-sea surveys to estimate size and temporal trends in seabird populations. J. Appl. Ecol. 40, 278-292.

Coachman, L.K., Walsh, J.J., 1981. A diffusion model of cross-shelf exchange of nutrients in the Southeastern Bering Sea. Deep Sea Res. 28, 819-846.

Croll, D.A., Gaston, A.J., Noble, D.G., 1991. Adaptive loss of mass in thick-billed murres. Condor 93, 496-502.

Croxall, J.P., Prince, P.A., 1996. Cephalapods as prey. 1. Seabirds. Philos. Trans. R. Soc. B. 351, 1023-1043.

Davoren, G.H., Burger, A.E., 1999. Differences in prey selection and behavior during self-feeding and chick provisioning in rhinoceros auklets. Anim. Behav. 58, 853-863.

Davoren, G.K., Montevecchi, W.A., 2003. Consequences of foraging trip duration on provisioning behavior and fledging condition of common murres Uria aalge. J Avian Biol. 34, 44-53.

Davoren, G.K., Montevecchi, W.A., Anderson, J.T., 2003. Distributional patterns of a marine bird and its prey: habitat selection based on prey and conspecific behavior. Mar. Ecol. Prog. Ser. 256, 229-242.

Decker, M.B., Hunt Jr., G.L., 1996. Foraging by murres (Uria spp.) at tidal fronts surrounding the Pribilof Islands, Alaska, USA. Mar. Ecol. Prog. Ser. 139, 1-10.

Doherty, P.F., Schreiber, E.A., Nichols, J.D., Hines, J.E., Link, W.A., Schenkm, G.A., Schreiber, R.W., 2004. Testing life history prediction in a long-lived seabird: a population matrix approach with improved parameter estimation. Oikos 105, 606-618.

Dorresteijn, I., Kitaysky, A.S., Barger, C., Benowitz-Fredericks, Z.M., Byrd, G.V. Shultz, M., Young, R., 2012. Climate affects food availability to planktivorous least auklets Aethia pusilla through physical processes in the southeastern Bering Sea. Mar. Ecol. Prog. Ser. 454, 207-220.

Emlen, J.M., 1966. The role of time and energy in food preference. Am. Naturalist $100,611-617$.
Erikstad, K.E., Asheim, M., Fauchald, P., Dahlhaug, L., Tveraa, T., 1997. Adjustment of parental effort in the puffin; the roles of adult body condition and chick size. Behav. Ecol. Sociobiol. 40, 95-100.

Fauchald, P., Erikstad, K.E., 2002. Scale-dependent predator-prey interactions: the aggregative response of seabirds to prey under variable prey abundance and patchiness. Mar. Ecol. Prog. Ser. 231, 279-291.

Forero, M.G., Hobson, K.A., Bortolotti, G.R., Donazar, J.A., Bertellotti, M., Blanco, G., 2002. Food resource utilization by the Magellanic penguin evaluated through stable-isotope analysis: segregation by sex and age and influence on offspring quality. Mar. Ecol. Prog. Ser. 234, 289-299.

Furness, B.L., Laugksch, R.C., Duffy, D.C., 1984. Cephalopod beaks and studies of seabird diets. Auk 101, 619-620.

Gabrielsen, G.W., 1994. Energy Expenditure in Arctic Seabirds. Ph.D. Thesis. University of Tromso, Norway.

Gaston, A.J., 1985a. Energy invested in reproduction by thick-billed murres (Uria lomvia). Auk 102, 447-458.

Gaston, A.J., 1985b. Development of the young in the Atlantic Alcidae. In: Nettleship, T.R., Birkhead, T.R. (Eds.), The Atlantic Alcidae. Academic Press, Toronto, pp. 319-354.

Gaston, A.J., Jones, I.L., 1998. The Auks. Oxford University Press, Oxford.

Gaston, A.J., Hipfner, J.M., 2000. Thick-billed Murre (Uria lomvia). In: Poole, A. (Ed.), The Birds of North America Online. Cornell Lab of Ornithology, Ithaca.

Golet, G.H., Irons, D.B., Estes, J.A., 1998. Survival costs of chick-rearing in blacklegged kittiwakes. J. Anim. Ecol. 67, 827-841.

Grebmeier, J.M., Overland, J.E., Moore, S.E., Farley, E.V., Carmack, E.C., Cooper, L.W., Frey, K.E., Helle, J.H., McLaughlin, F.A., McNutt, S.L., 2006. A major ecosystem shift in the Northern Bering Sea. Science 311, 1461-1464.

Hollowed, A.B., Barbeaux, S.J., Cokelet, E.D., Farley, A., Kotwicki, S., Ressler, P.H., Spital, C., Wilson, C.D., 2012. Effects of climate variations on pelagic ocean habitats and their role in structuring forage fish distributions in the Bering Sea. Deep Sea Res. II 65-70, 230-250.

Hamer, K.C., Humphreys, E.M., Magalhães, M.C., Garthe, S., Hennicke, J., Peters, G., Grémillet, D., Skov, H., Wanless, S., 2009. Fine-scale foraging behavior of a medium-ranging marine predator. J. Anim. Ecol. 78, 880-889.

Harding, A.M.A., Piatt, J.F., Schmutz, J.A., Kettle, A.B., Shultz, M., Van Pelt, T.I., Kettle, A.B., Speckman, S.G., 2007. Prey density and the behavioural flexibility of a marine predator: the common murre (Uria aalge). Ecology 88 (8), 2024-2035.

Hare, S.R., Mantua, N.J., 2000. Empirical evidence for North Pacific regime shifts in 1977 and 1989. Prog. Oceanogr. 47, 103-1445.

Harris, M.P., Wanless, S., 1995. The food consumption of young common murres (Uria aalge) in the Wild. Colonial Waterbirds 18, 209-213.

Harris, M.P., Wanless, S., 1988. The breeding biology of Guillemots Uria aalge on the Isle of May over a six year period. Ibis 130, 172-192.

Hedd, A., Regular, P.M., Montevecchi, W.A., Buren, A.D., Burke, C.M., Fifield, D.A., 2009. Going deep: common murres dive into frigid water for aggregated, persistent and slow-moving capelin. Mar. Biol. 156, 741-751.

Hogan, G.G., 1985. Noosing adult cormorants for banding. N. Am. Bird Bander 10, 76-77.

Houston, A.I., 2002. Prey size of single-prey loaders as an indicator of prey abundance. Ecol. Lett. 3 (1), 5-6.

Houston, A.I., McNamara, J.M., 1985. A general theory of central-place foraging for single-prey loaders. Theor. Popul. Biol. 28, 233-262.

Houston, A.I., Thompson, W.A., Gaston, A.J., 1996. The use of a time and energy budget model of a parent bird to investigate limits to fledging mass in the thick-billed murre. Funct. Ecol. 10, 432-439.

Ito, M., Takahashi, A., Kokubun, N., Kitaysky, A.S., Watanuki, Y., 2010. Foraging behavior of incubating and chick-rearing thick-billed murres Uria lomvia. Aquat. Biol. 8, 279-287.

Iverson, S.J., Springer, A.M., Kitaysky, A.S., 2007. Seabirds as indicators of food web structure and ecosystem variability: qualitative and quantitative analysis using fatty acids. Mar. Ecol. Prog. Ser. 352, 235-244.

Janelli, J.N., Barbeaux, S., Honkalehto, T., Kotwicki, S., Aydin, K., and Williamson, N., 2009. Chapter $1 \& 1 \mathrm{~B}$. Assessment of walleye Pollock in the Eastern Bering Sea and Bogoslof Region. In: Stock Assessment and Fishery Evaluation Report for the Groundfish Resources of the Bering Sea/Aleutian Islands Regions. North Pacific Fishery Management Council, Anchorage, AK, p. 47-234.

Kacelnik, A., Cuthill, I., 1990. Central place foraging in starlings (Sturnus vulgaris). II. Food allocation to chicks. J. Anim. Ecol. 59, 655-674.

Katugin, O.N., Zuev, N.N., 2007. Distribution of cephalopods in the upper epipelagic northwestern Bering Sea in autumn. Rev. Fish Biol. Fish. 17, 283-294.

Kitaysky, A.S., Piatt, J.F., Wingfield, J.C., Romano, M., 1999a. The adrenocorticol stress-response of black-legged kittiwake chicks in relation to dietary restrictions. J. Comp. Physiol. B 169, 303-310.

Kitaysky, A.S., Wingfield, J.C., Piatt, J.F., 1999b. Dynamics of food availability, body condition and physiological stress response in breeding Black-legged Kittiwakes. Funct. Ecol. 13, 577-584.

Kitaysky, A.S., Hunt, G.L., Flint, E.N., Rubega, M.A., Decker, M.B., 2000. Resource allocation in breeding seabirds: responses to fluctuations in their food supply. Mar. Ecol. Prog. Ser. 283, 283-296.

Kitaysky, A.S., Piatt, J.F., Wingfield, J.C., 2007. Stress hormones link food availability and population processes in seabirds. Mar. Ecol. Prog. Ser. 352, 245-258.

Kitaysky, A.S., Piatt, J.F., Hatch, S.A., Kitaiskaia, E.V., Benowitz-Fredericks, Z.M., Shultz, M.T., Wingfield, J.C., 2010. Food availability and population processes: severity of nutritional stress during reproduction predicts survival of longlived seabirds. Funct. Ecol. 24, 625-637. 
Kokubun, N., Iida, K., Mukai, T., 2008. Distribution of murres (Uria spp.) and their prey south of St. George Island in the southeastern Bering Sea during the summers of 2003-2005. Deep-Sea Res. II 55, 1827-1836.

Kooyman, G.L., Cherel, Y., Le Mayo, Y., Croxall, J.P., Thorson, P.H., Ridoux, V., Kooyman, C.A., 1992. Diving behavior and energetics during foraging cycles in king penguins. Ecol. Monogr. 62, 143-163.

Kotliar, N.B., Wiens, J.A., 1990. Multiple scales of patchiness and patch structure: a hierarchical framework for the study of heterogeneity. Oikos 59, 243-260.

Ladd, C., Jahncke, J., Hunt Jr., G.L., Coyle, K.O., Stabeno, P.J., 2005. Hydrographic features and seabird foraging in Aleutian Passes. Fish Oceanogr. 14 (Suppl. 1), 178-195.

Lance, B.K., Roby, D.D., 2000. Diet and postnatal growth in red-legged and blacklegged kittiwakes: an interspecies cross-fostering experiment. Auk 117, 1016-1028.

Le Boeuf, B.J., Crocker, D.E., Costa, D.P., Blackwell, S.B., Webb, P.M., Houser, D.S., 2000. Foraging ecology of northern elephant seals. Ecol. Monogr. 70, 353-382.

Lewis, S., Sherratt, T.N., Hamer, K.C., Wanless, S., 2001. Evidence of intra-specific competition for food in a pelagic seabird. Nature 412, 816-819.

Litzow, M.A., Bailey, K.M., Prahl, F.G., Heintz, R., 2006. Climate regime shifts and reorganization of fish communities: the essential fatty acid limitation hypothesis. Mar. Ecol. Prog. Ser. 315, 1-11.

Logerwell, E.A., Schaufler, L.E., 2005. New data on proximate composition and energy density of Steller sea lion (Eumetopias jubatus) prey fills seasonal and geographic gaps in existing information. Aquat. Mammals 31, 62-82.

Mackas, D.L., Tsurumi, M., Galbraith, M.D., Yelland, D.R., 2005. Zooplankton distribution and dynamics in a North Pacific Eddy of coastal origin: II. Mechanisms of eddy colonization by and retention of offshore species. Deep-Sea Res. II 52, 1011-1035.

Maravelias, C.D., Reid, D.G., Simmonds, E.J., Haralabous, J., 1996. Spatial analysis and mapping of acoustic survey data in the presence of high local variability: geostatistical application to North Sea herring (Clupeaharengus). Can. J. Fish. Aquat.Sci. 53, 1497-1505.

Martindale, S., 1982. Nest defense and central place foraging: a model and experiment. Behav. Ecol. Sociobiol. 10, 85-89.

McArthur, R.H., Pianka, E.R., 1966. Optimal use of a patchy environment. Am. Naturalist 100, 603-609.

McConnell, B.J., Chambers, C., Fedak, M.A., 1992. Foraging ecology of southern elephant seals in relation to the bathymetry and productivity of the Southern Ocean. Antarct. Sci. 4, 393-398.

Moku, M., Kawaguchi, K., Watanabe, H., Ohno, A., 2000. Feeding habits of three dominant myctophid fishes, Diaphus theta, Stenobrachius leucopsarus and S. nannochir, in the subarctic and transitional waters of the western North Pacific. Mar. Ecol. Prog. Ser. 207, 129-140.

Mordy, C.W., Stabeno, P.J., Ladd, C., Zeeman, S., Wisegarver, D.P., Salo, S.A., Hunt Jr., G.L., 2005. Nutrients and primary production along the eastern Aleutian Island Archipelago. Fish. Oceanogr. 14, 55-76.

Neves, V.C., Bolton, M., Monteiro, L.R., 2006. Validation of the water offloading technique for diet assessment: an experimental study with Cory's shearwaters (Calonectris diomedea). J. Ornithol. 147, 474-478.

Orians, G.H., Pearson, N.E., 1979. On the theory of central place foraging. In: Horn, D.J., Mitchell, R.D., Stairs, G.R. (Eds.), Analysis of Ecological Systems. Ohio State University Press, Columbus, Ohio, USA, pp. 154-177.

Paredes, R., Jones, I.L., Boness, D.J., 2005. Reduced parental care, compensatory behavior and reproductive costs experienced by female and male thick-billed murres equipped with data loggers. Anim. Behav. 69, 197-208.

Passos, C., Navarro, J., Giudici, A., González-Solís, J., 2010. Effects of extra mass on the pelagic behavior of a seabird. Auk 127, 100-107.

Pennycuick, C.J., 1987. Flight of auks (alcidae) and other northern seabirds compared with southern procellariformes: Ornithodolite observations. J. Exp. Biol. 128, 335-347.

Philips, R.A., Xavier, J.C., Croxall, J.P., 2003. Effects of satellite transmitters on albatross and petrels. Auk 120, 1082-1090.

Piatt, J.F., Springer, A.M., 2003. Advection, Pelagic Food webs and the biogeography of seabirds in Beringia. Mar. Ornithol. 31, 141-154.

Piatt, J.F., Harding, A.M.A., Shultz, M., Speckman, S.G., Van Pelt, T.I., Drew, G.S., Kettle, A.B., 2007. Seabirds as indicators of marine food supplies: cairns revisited. Mar. Ecol. Prog. Ser. 352, 221-234.

Polovina, J.J., Howell, E., Kobayashi, D.R., Seki, M.P., 2001. The transition zone chlorophyll front, a dynamic global feature defining migration and forage habitat for marine resources. Prog. Oceanogr. 49, 469-483.

Radchenko, V.I., 1992. The role of squids in the pelagic ecosystem of the Bering Sea. Oceanology 32, 1093-1101.

Raouf, S.A., Smith, L.C., Brown, M.B., Wingfield, J.C., Brown, C.R., 2006. Glucocorticoid hormone levels increase with growth size and parasite load in cliff swallows. Anim. Behav. 71, 39-48.

Renner, H.M., Mueter, F., Drummond, B.A., Warzybok, J.A., Sinclair, E.H., 2012. Patterns of change in diets of two piscivorous seabird species during 35 years in the Pribilof Islands. Deep-Sea Res. II 65-70, 273-291.

Romano, M.D., Piatt, J.F., Roby, D.D., 2006. Testing the junk-food hypothesis on marine birds: effects of prey type on growth and development. Waterbirds 29, 407-516.

Romero, L.M., Wikelski, M., 2001. Corticosterone levels predict survival probabilities of Galapagos marine aguanas during El Niño events. Proc. Natl. Acad. Sci. $98,7366-7370$
Romero, L.M., Reed, M.J., Wingfield, J.C., 2000. Effects of weather on corticosterone responses in wild free-living passerine birds. Gen. Comp. Endocrinol. 118, 113-122.

Ryan, P.G., Petersen, S.L., Peters, G., Grémillet, D., 2004. GPS tracking a marine predator: the effects of precision, resolution and sampling rate on foraging tracks on African Penguins. Mar. Biol. 145 (2), 215-223.

Russell, R.W., Hunt, G.L., Coyle, K.O., Cooney, R.T., 1992. Foraging in a fractura environment: spatial patterns in a marine predator-prey system. Landscape Ecol. 7, 195-209.

Satterthwaite, W.H., Kitaysky, A.S., Hatch, S.A., Piatt, J.F., Mangel, M., 2010 Unifying quantitative life history theory and field endocrinology to assess prudent parenthood in a long-lived seabird. Evol. Ecol. Res. 12, 779-792.

Satterthwaite, W.H., Kitaysky, A.S., Mangel, M., 2012. Linking climate variability, productivity and stress to demography in a long-lived seabird. Mar. Ecol. Prog. Ser. 454, 221-235.

Schneider, D.C., 1982. Fronts and seabird aggregations in the southeastern Bering Sea. Mar. Ecol. Prog. Ser. 10, 101-103.

Schneider, D.C., Hunt, G.L., 1984. A comparison of seabird diets and foraging distribution around the Pribilof Islands, Alaska. In: Nettleship, D.N., Sanger G.A., Springer, P.F. (Eds.), Marine Birds: Their Feeding Ecology and Commercial Fisheries Relationships. Special Publication, Canadian Wildlife Service, Ottawa, pp. 86-95.

Schoener, T.W., 1971. Theory of feeding strategies. Annu. Rev. Ecol. Syst. 2 369-404.

Schultner, J., Kitaysky, A.S., Welcker, W., 2013. Fat or lean: adjustment of endogenous energy stores to predictable and unpredictable changes in allostatic load. Funct. Ecol. 27, 45-55.

Schumacher, J.D., Reed, R.K., 1992. Characteristics of currents over the continental slope of the eastern Bering Sea. J. Phys. Oceanogr. 97, 9423-9433.

Sinclair, E.H., Balanov, A.A., Kubodera, T., Radchenko, V.I., Fedorets, Y.A., 1999 Distribution and ecology of mesopelagic fishes and cephalopods. In: Loughlin, T.R., Ohtani, K. (Eds.), Dynamics of the Bering Sea. University of Alaska Sea Grant, Fairbanks, Alaska, pp. 485-508 99775-5040.

Sinclair, E.H., Stabeno, P.J., 2002. Mesopelagic nekton and associated physics of the southeastern Bering Sea. Deep-Sea Res. II 49, 6127-6145.

Sinclair, E.H., Vlietstra, L.S., Johnson, D.S., Zeppelin, T.K., Byrd, G.V., Springer, A.M. Ream, R.R., Hunt, G.L., 2008. Patterns in prey use among fur seals and seabirds in the Pribilof Islands. Deep-Sea Res. II 55, 1897-1918.

Skov, H., Humphreys, E., Garthe, S., Geitner, K., Hamer, K., Hennicke, J., Parner, H., Grémillet, D., Wanless, S., 2008. Application of habitat suitability modelling to tracking data of marine animals as a means of analyzing their feeding habitats. Ecol. Model. 212, 504-512.

Springer, A.M., McRoy, C.P., 1993. The paradox of pelagic food webs in the northern Bering Sea-III. Patterns of primary production. Cont. Shelf Res. 13, 575-599.

Springer, A.M., McRoy, C.P., Flint, M.V., 1996. The Bering Sea Green Belt: shelf-edge processes and ecosystem production. Fish. Oceanogr. 5, 205-223.

Stabeno, P.J., Kachel, N.B., Moore, S.E., Napp, J.M., Sigler, M., Yamaguchi, A., Zerbini, A.N., 2012. Comparison of warm and cold years on the southeastern Bering Sea shelf and some implications for the ecosystem. Deep-Sea Res. II 65-70, 31-45.

Takahashi, A., Matsumoto, K., Hunt, G.L., Shultz, M.T., Kitaysky, A.S., Sato, K., Iida, K., Watanuki, Y., 2008. Thick-billed murres use different diving behaviors in mixed and stratified waters. Deep-Sea Res. II 55, 1837-1845.

Trathan, P.N., Murphy, E.J., Croxall, J.P., Everson, I., 1998. Use of at-sea distribution data to derive potential foraging ranges of macaroni penguins during the breeding season. Mar. Ecol. Prog. Ser. 169, 262-275.

Tremblay, Y., Cherel, Y., Oremus, M., Tveraa, T. Chastel., O., 2003. Unconventional ventral attachment of time-depth recorders as a new method for investigating time budget and diving behavior of seabirds. J. Exp. Biol. 206 1929-1940.

Van Pelt, T.I., Piatt, J.F., Lance, B.K., Roby, D.D., 1997. Proximate composition and energy density of some North Pacific forage fishes. Comp. Biochem. Physiol. A. $118,1393-1398$.

Visser, A., Jonasdottir, S., 1999. Lipids, buoyancy and the seasonal vertical migration of Calanus finmarchicus. Fish. Oceanogr. 8, 100-106.

Watanuki, Y., Mehlum, F., Takahashi, A., 2001. Water temperature sampling by foraging Brünnich's guillemots with bird-borne data loggers. J. Avian Biol. 32, 189-193.

Weimerskirch, H., 2007. Are seabirds foraging for unpredictable resources? DeepSea Res. II 54, 211-223.

Weimerskirch, H., Chastel, O., Ackermann, L., Chaurand, T., Cuenot-Chaillet, F. Hindermeyer, X., Judas, J., 1994. Alternate long and short foraging trips in pelagic seabird parents. Anim. Behav. 47, 372-476.

Welcker, J., Harding, A.M.A., Kitaysky, A.S., Speakman, J.R., Gabrielsen, G.W., 2009 Daily energy expenditure increases in response to low nutritiojnal stress in an Arctic-breeding seabird with no effect of mortality. Funct. Ecol. 107, $1-97$.

Whitman, L.D., 2010. Variation in the Density of Forage Fishes and Invertebrates from the Southeastern Bering Sea. M.Sc. Thesis. University of Oregon. USA.

Wilson, R.P., 1984. An improved stomach pump for penguins and other seabirds. J. Field Ornithol 55 (1), 109-112.

Wilson, R.P., La Cok, G.D., Wilson, M.P., Mollagee, F., 1985. Differential digestion of fish and squid in jackass penguins Spheniscusdemersus. Ornis Scand. 16, 77-79. 
Wilson, R.P., Grémillet, D., Syder, J., Kierspel, M.A.M., Garthe, S., Weimerskirch, H., Schäfer-Neth, C., Scolara, J.A., Bost, C.-A., Plötz, J., Nel, D., 2002. Remote-sensing systems and seabirds; their use, abuse and potential for measuring marine environmental variables. Mar. Ecol. Prog. Ser. 228, 241-261.

Wilson, R.P., Scolaro, J.A., Grémillet, D., Kierspel, M.A.M., Laurenti, S., Upton, J., Gallelli, H., Quintana, F., Frere, E., Müller, G., Straten, M.T., Zimmer, I., 2005.
How do magallanic penguins cope with variability in their access to prey? Ecol. Monogr. 75, 379-401.

Wingfield, J.C., Maney, D.L., Breuner, C.W., Jacobs, J.D., Lynn, S., Ramenofsky, M., Richardson, R.D., 1998. Ecological basis of hormone-behavior interactions: the "Emergency Life History Stage". Am. Zool. 38, 191-206. 